\title{
Influence of isoprene chemical mechanism on modelled changes in tropospheric ozone due to climate and land use over the 21st century
}

\author{
O. J. Squire ${ }^{1}$, A. T. Archibald ${ }^{1,2}$, P. T. Griffiths ${ }^{1}$, M. E. Jenkin ${ }^{3}$, D. Smith ${ }^{1}$, and J. A. Pyle ${ }^{1,2}$ \\ ${ }^{1}$ Centre for Atmospheric Science, Department of Chemistry, University of Cambridge, Cambridge, CB2 1EW, UK \\ ${ }^{2}$ National Centre for Atmospheric Science, Department of Chemistry, University of Cambridge, Cambridge, CB2 1EW, UK \\ ${ }^{3}$ Atmospheric Chemistry Services, Okehampton, Devon EX20 1FB, UK
}

Correspondence to: O. J. Squire (ojsquire@gmail.com)

Received: 7 July 2014 - Published in Atmos. Chem. Phys. Discuss.: 1 September 2014

Revised: 2 April 2015 - Accepted: 10 April 2015 - Published: 7 May 2015

\begin{abstract}
Isoprene is a precursor to tropospheric ozone, a key pollutant and greenhouse gas. Anthropogenic activity over the coming century is likely to cause large changes in atmospheric $\mathrm{CO}_{2}$ levels, climate and land use, all of which will alter the global vegetation distribution leading to changes in isoprene emissions. Previous studies have used global chemistry-climate models to assess how possible changes in climate and land use could affect isoprene emissions and hence tropospheric ozone. The chemistry of isoprene oxidation, which can alter the concentration of ozone, is highly complex, therefore it must be parameterised in these models. In this work, we compare the effect of four different reduced isoprene chemical mechanisms, all currently used in Earth system models, on tropospheric ozone. Using a box model we compare ozone in these reduced schemes to that in a more explicit scheme (the Master Chemical Mechanism) over a range of $\mathrm{NO}_{x}$ and isoprene emissions, through the use of $\mathrm{O}_{3}$ isopleths. We find that there is some variability, especially at high isoprene emissions, caused by differences in isoprene-derived $\mathrm{NO}_{x}$ reservoir species. A global model is then used to examine how the different reduced schemes respond to potential future changes in climate, isoprene emissions, anthropogenic emissions and land use change. We find that, particularly in isoprene-rich regions, the response of the schemes varies considerably. The wide-ranging response is due to differences in the model descriptions of the peroxy radical chemistry, particularly their relative rates of reaction towards $\mathrm{NO}$, leading to ozone formation, or $\mathrm{HO}_{2}$, leading to termination. Also important is the yield of isoprene nitrates and peroxyacyl nitrate precursors from isoprene oxidation. Those schemes that produce less of these $\mathrm{NO}_{x}$ reservoir
\end{abstract}

species, tend to produce more ozone locally and less away from the source region. We also note changes in other key oxidants such as $\mathrm{NO}_{3}$ and $\mathrm{OH}$ (due to the inclusion of additional isoprene-derived $\mathrm{HO}_{x}$ recycling pathways). These have implications for secondary organic aerosol formation, as does the inclusion of an epoxide formation pathway in one of the mechanisms. By combining the emissions and $\mathrm{O}_{3}$ data from all of the global model integrations, we are able to construct isopleth plots comparable to those from the box model analysis. We find that the global and box model isopleths show good qualitative agreement, suggesting that comparing chemical mechanisms with a box model in this framework is a useful tool for assessing mechanistic performance in complex global models. We conclude that as the choice of reduced isoprene mechanism may alter both the magnitude and sign of the ozone response, how isoprene chemistry is parameterised in perturbation experiments such as these is a crucially important consideration. More measurements and laboratory studies are needed to validate these reduced mechanisms especially under high-volatile-organiccompound, low- $\mathrm{NO}_{x}$ conditions.

\section{Introduction}

The emission of volatile organic compounds (VOCs) into the atmosphere in the presence of $\mathrm{NO}_{x}$ (the sum of nitric oxide (NO) and nitrogen dioxide $\left(\mathrm{NO}_{2}\right)$ ) can lead to the formation of tropospheric ozone $\left(\mathrm{O}_{3}\right)$, which is a pollutant and greenhouse gas (e.g. Haagen-Smit, 1952). One VOC that contributes significantly to tropospheric $\mathrm{O}_{3}$ production 
is the biogenically emitted di-alkene isoprene (2-methyl-1,3butadiene) with annual emissions of $\sim 500 \mathrm{Tg} \mathrm{C}$ (Guenther et al., 2006). Isoprene is highly reactive with an atmospheric lifetime on the order of about $1-2 \mathrm{~h}$, and thus has the potential to strongly influence levels of tropospheric $\mathrm{O}_{3}$ both regionally (e.g. Chameides et al., 1988) and globally (e.g. Wang and Shallcross, 2000).

Isoprene is oxidised in the atmosphere by the hydroxyl radical $(\mathrm{OH}), \mathrm{O}_{3}$ and the nitrate radical $\left(\mathrm{NO}_{3}\right)$. These reactions initiate a complex cascade of photochemical interactions, which (theoretically) comprise $>10^{5}$ reactions involving $>10^{4}$ species (Aumont et al., 2005). Including all of these reactions in 3-D global modelling studies is too computationally expensive and so isoprene chemistry must be parameterised. Furthermore, our understanding of isoprene oxidation is incomplete; only a small number of these $10^{5}$ reactions are known in depth. Although parameterisation is a necessity, it introduces uncertainties in the chemistry and subsequent calculation of trace gas composition, as multiple species or reactions have to be lumped together. Furthermore, there are several different methodologies for how best to parameterise an explicit chemical mechanism, which has led to the existence of a plethora of different reduced schemes, whose use in models can lead to different results (e.g. Archibald et al., 2010b). Jeffries et al. (1992) laid out a set of basic considerations to make when evaluating a condensed chemical mechanism, which are the points in the process of condensed mechanism development where individual methodologies may diverge. These include the relationship between different lumping groups and explicit species, the method used to select individual lumping groups, e.g. by characteristic reaction times, molecular weight or chemical structure, and the approach to handling chain degradation kinetics for each lumped species. The choices made in developing reduced mechanisms may also have been made with the aim of accurately representing specific timescales (e.g. urban or continental) or species (e.g. O 3 ) (Jeffries et al., 1992).

To date there have been several studies that calculate the effects of future isoprene emission changes caused by potential climate and land use scenarios on surface $\mathrm{O}_{3}$ (Sanderson et al., 2003; Wiedinmyer et al., 2006; Ganzeveld et al., 2010; Wu et al., 2012; Pacifico et al., 2012), including our recent study (Squire et al., 2014). These 3-D global modelling studies all use (often different) reduced isoprene mechanisms. Very few studies, however, have attempted to quantify the influence of differences in the isoprene scheme on the $\mathrm{O}_{3}$ response. Previously, von Kuhlmann et al. (2004) compared three different isoprene mechanisms and related parameters such as the deposition of intermediates, the treatment of isoprene nitrates and the emission strength of $\mathrm{O}_{3}$ precursors, all within a particular global model. Here we explore the behaviour of four reduced schemes, all designed to be used in complex Earth system models (ESMs), in the context of the climate and land use perturbation experiments carried out in Squire et al. (2014). Given the importance of $\mathrm{O}_{3}$ in the
Earth system (Huntingford et al., 2011), our analysis focuses specifically on $\mathrm{O}_{3}$ and on $\mathrm{O}_{3}$ precursors.

Even without mechanism reduction, there exist sources of uncertainty in isoprene oxidation that are associated with our fundamental lack of understanding about certain aspects of the chemistry. One such aspect is the degree to which $\mathrm{HO}_{x}$ is regenerated from isoprene degradation under low$\mathrm{NO}_{x}$ high-VOC conditions. Several campaigns in such conditions (GABRIEL, Kubistin et al., 2010; INTEX-A, Ren et al., 2008; OP3, Stone et al., 2011; Whalley et al., 2011) reported levels of $\mathrm{HO}_{x}$ that were higher than expected, considering the high reactivity of isoprene with $\mathrm{OH}\left(k_{298 \mathrm{~K}}=\right.$ $10^{-10} \mathrm{~cm}^{3}$ molecule $\mathrm{e}^{-1} \mathrm{~s}^{-1}$ ). Proposals have been put forward for missing mechanistic pathways, e.g. peroxy radical isomerisation (Peeters et al., 2009), and epoxide formation (Paulot et al., 2009) which to some extent reconcile these discrepancies (Archibald et al., 2010a; Warwick et al., 2013; Fuchs et al., 2013). It has also been demonstrated that positive biases in the measurement of $\mathrm{HO}_{2}$ (Fuchs et al., 2011) and $\mathrm{OH}$ (Mao et al., 2012) cannot be ruled out in some of those field campaigns listed above. Mao et al. (2012) found that, for a Californian forest environment, taking into account these biases in addition to the proposed mechanistic pathways, gave good agreement between modelled and measured $\mathrm{HO}_{x}$.

The chemistry of isoprene nitrates represents another important source of uncertainty. When hydroxyperoxy radicals from $\mathrm{OH}$-initiated isoprene oxidation $\left(\mathrm{ISO}_{2}\right)$ react with $\mathrm{NO}$, the major pathway leads to the formation of alkoxy radicals and $\mathrm{NO}_{2}$ (leading to $\mathrm{O}_{3}$ formation). However, there is a minor channel that leads to the formation of isoprene nitrates, which act to sequester $\mathrm{NO}_{x}$. There are several uncertainties surrounding the chemistry of isoprene nitrates. First, estimates of the yield of isoprene nitrates from the $\mathrm{OH} / \mathrm{NO}$ channel range from 4.4 to $15 \%$ (Xie et al., 2013, and references therein). Modelling studies have shown that the assumed yield of isoprene nitrates can have a large impact on tropospheric $\mathrm{O}_{3}$ (e.g. von Kuhlmann et al., 2004; Wu et al., 2007; Paulot et al., 2012). Second, isoprene nitrates may also be formed from the oxidation of isoprene by $\mathrm{NO}_{3}$, which is estimated to account for $30-60 \%$ of isoprene nitrate production (von Kuhlmann et al., 2004; Horowitz et al., 2007; Paulot et al., 2012). The types of isoprene nitrates formed via the $\mathrm{NO}_{3}$ pathway are distinct from those formed via the $\mathrm{OH} / \mathrm{NO}$ pathway and details of their atmospheric fates remain relatively obscure (Xie et al., 2013). Third, once formed, isoprene nitrates are readily photooxidised (lifetime $\sim 4 \mathrm{~h}$ with respect to $\mathrm{OH}\left(\mathrm{OH}=10^{6}\right.$ molecule $\left.\left.\mathrm{cm}^{-3}\right)\right)$, leading either to release of $\mathrm{NO}_{x}$, or to second-generation nitrates, retaining the nitrate group. The degree to which $\mathrm{NO}_{x}$ is regenerated from isoprene nitrate degradation remains uncertain (Fiore et al., 2012; Xie et al., 2013) and has a significant effect on the $\mathrm{O}_{3}$ response to isoprene emission changes (Paulot et al., 2012). Fourth, dry deposition of isoprene nitrates, which may represent an important $\mathrm{NO}_{x}$ sink 
in isoprene-rich regions, is also uncertain, with measured deposition velocities ranging from $0.4 \mathrm{~cm} \mathrm{~s}^{-1}$ (Shepson et al., 1996) to $2.7 \mathrm{~cm} \mathrm{~s}^{-1}$ (Farmer and Cohen, 2008). Finally, there is evidence for the importance of $\mathrm{O}_{3}$-initiated isoprene nitrate degradation (Lockwood et al., 2010) and fast photolysis of isoprene nitrates (Müller et al., 2014). In this study, the isoprene schemes we compare have a range of different parameterisations for isoprene nitrates.

In Sect. 2, we describe in detail the four chemical mechanisms used in this study and the methodology for the global perturbation experiments. In Sect. 3, we discuss the results of a series of box model simulations with the aim of comparing the four reduced mechanisms to the Master Chemical Mechanism (MCM). This is done for a range of $\mathrm{NO}_{x}$ and isoprene concentrations. Global integrations with each mechanism are then conducted to examine the effect of changes in climate, in isoprene emissions with climate, in anthropogenic emissions and in land use. In Sects. 4-6, we analyse the results of these global perturbation experiments.

\section{Methods}

In this section, we outline the experiments conducted to ascertain the effect of using different reduced isoprene chemical mechanisms in the context of global climate, emissions and land use change experiments (Sect. 2.2.2). In Sect. 2.1, details of the reactions and species that make up the reduced mechanisms are given.

\subsection{Isoprene chemical mechanisms}

The species included in each mechanism are given in Table 1, whilst a comparison of the reactions is given in Table 2. The different isoprene mechanisms were each embedded in an otherwise identical tropospheric chemistry mechanism simulating the chemistry of methane, ethane, propane, $\mathrm{HO}_{x}$ and $\mathrm{NO}_{x}$, following O'Connor et al. (2014).

The first simulation used the UM-UKCA Chemistry of the Troposphere (CheT) mechanism, as was done for all integrations in Squire et al. (2014). The CheT isoprene mechanism consists of 16 species and 44 reactions (see Tables 1 and 2), and is based on the Mainz Isoprene Mechanism (MIM) (Pöschl et al., 2000). MIM was developed from a reduction of the Master Chemical Mechanism (version 2) (Jenkin et al., 1997), by lumping species based on their structure (e.g. all hydroxyperoxy radicals were lumped as $\mathrm{ISO}_{2}$, and methacrolein and methyl vinyl ketone as methacrolein, MACR). The overall CheT mechanism also forms the base case against which all the schemes studied, are compared.

Since the creation of MIM, there have been a number of developments in our understanding of isoprene chemistry concerning issues such as those discussed in the Introduction. In a report compiled for the UK Met Office (Jenkin, 2012), these new developments were incorporated into the current CheT framework. The resulting updated mechanism (which will be referred to as CheT2, see Tables 1 and 2) is the most complex mechanism used in this study, consisting of 24 species and 59 reactions, and is traceable to the MCM version 3.2 (MCMv3.2).

The following is a summary of the changes introduced into the CheT mechanism to create CheT2. First, changes to the chemistry of first-generation isoprene nitrates (ISON) were made. In CheT, $\mathrm{NO}_{x}$ is regenerated from ISON by photolysis or conversion to second-generation nitrates (NALD) followed by reaction with $\mathrm{OH}$. In CheT2, the overall yield of $\mathrm{NO}_{x}$ from ISON was increased, in line with recent measurements (Perring et al., 2009), by increasing the ISON photolysis rate and adding an ISON $+\mathrm{OH} \rightarrow \mathrm{NO}_{2}$ reaction channel. $\mathrm{O}_{3}$ initiated degradation of ISON was also added based on the evidence of Lockwood et al. (2010) - it should be noted, however, that Lee et al. (2014) found that Lockwood et al. (2010) substantially overestimated the rate of this reaction. Secondly, CheT2 includes the formation of hydroperoxy-aldehydes (HPALDs) from $\mathrm{ISO}_{2}$ and subsequent rapid release of $\mathrm{OH}$ (Peeters et al., 2009). This leads to more $\mathrm{HO}_{x}$ regeneration in low- $\mathrm{NO}_{x}$ high-isoprene conditions, bringing modelled and measured values closer together (e.g. Archibald et al., 2010a). The formation of isoprene epoxydiols (IEPOX) from the oxidation of isoprene hydroxy-hydroperoxides (ISOOH), a potential source of secondary organic aerosols (Paulot et al., 2009), was also included in CheT2. Finally, the yield of peroxymethacrylic nitric anhydride (MPAN) from isoprene oxidation was revised down from its CheT value (Jenkin, 2012).

The Air Quality in the Unified Model (AQUM) scheme, which was developed to deliver regional air quality forecasts and conduct air quality studies to inform emission control policies (Savage et al., 2013), was also investigated. The mechanism has a more anthropogenic VOC focus and a less detailed isoprene scheme compared with CheT (17 species, 23 reactions). Two important simplifications in the isoprene scheme are that (1) isoprene nitrates are not formed from the $\mathrm{OH}$ initiated pathway via the reaction of $\mathrm{ISO}_{2}$ with $\mathrm{NO}$, and (2) there is no production of MPAN.

The last and most simple isoprene scheme investigated was the super-fast chemistry scheme developed at the Lawrence Livermore National Laboratory (LLSF) (Cameron-Smith et al., 2009) for use in the Community Earth System Model (CESM - http://www.cesm.ucar.edu/ models/cesm1.0/). The LLSF isoprene scheme only considers the reactions of isoprene with $\mathrm{OH}$ and $\mathrm{O}_{3}$, and was parameterised based on the net effect of a more complex isoprene mechanism (Cameron-Smith et al., 2009). Aside from not including isoprene chemistry at all, it is about as simple an approximation of isoprene chemistry as is currently used in ESMs, but is still a significant improvement over neglecting isoprene chemistry altogether (Cameron-Smith et al., 2009). The scheme was developed for use in very long 
Table 1. List of chemical species included in each of the isoprene mechanisms. Note that names of some of the species in AQUM were changed from the names given in Savage et al. (2013) to be consistent with the other schemes. These are as follows: "HOIPO2" - ISO 2 , "MVK" - MACR, "MVKOOH" - MACROOH, "HOMVKO2" - $\mathrm{MACRO}_{2}$.

\begin{tabular}{|c|c|c|c|c|c|}
\hline Species & Description & CheT & CheT2 & AQUM & LLSF \\
\hline $\mathrm{C}_{5} \mathrm{H}_{8}$ & isoprene & $\mathrm{X}$ & $X$ & $\mathrm{X}$ & $\mathrm{X}$ \\
\hline $\mathrm{ISO}_{2}$ & $\begin{array}{l}\text { hydroxyperoxy radicals } \\
\text { from } \mathrm{C}_{5} \mathrm{H}_{8}+\mathrm{OH}\end{array}$ & $\mathrm{X}$ & $\mathrm{X}$ & $\mathrm{X}$ & \\
\hline ISOOH & $\begin{array}{l}\beta \text {-hydroxyhydro- } \\
\text { peroxides from } \\
\mathrm{ISO}_{2}+\mathrm{HO}_{2}\end{array}$ & $\mathrm{X}$ & $\mathrm{X}$ & $\mathrm{X}$ & \\
\hline ISON & $\begin{array}{l}\beta \text {-hydroxy alkylnitrates } \\
\text { from } \mathrm{ISO}_{2}+\mathrm{NO} \text { and } \\
\text { alkyl nitrates from } \\
\mathrm{C}_{5} \mathrm{H}_{8}+\mathrm{NO}_{3}\end{array}$ & $\mathrm{X}$ & $\mathrm{X}$ & $\mathrm{X}$ & \\
\hline MACR & $\begin{array}{l}\text { methacrolein, } \\
\text { methyl vinyl ketone } \\
\text { and other } \mathrm{C}_{4} \text {-carbonyls }\end{array}$ & $\mathrm{X}$ & $\mathrm{X}$ & $\mathrm{X}$ & \\
\hline $\mathrm{MACRO}_{2}$ & $\begin{array}{l}\text { peroxy radicals } \\
\text { from MACR }+\mathrm{OH}\end{array}$ & $\mathrm{X}$ & $\mathrm{X}$ & $\mathrm{X}$ & \\
\hline MACROOH & $\begin{array}{l}\text { hydroperoxides } \\
\text { from } \mathrm{MACRO}_{2}+\mathrm{HO}_{2}\end{array}$ & $\mathrm{X}$ & $\mathrm{X}$ & $\mathrm{X}$ & \\
\hline MPAN & $\begin{array}{l}\text { peroxymethacrylic } \\
\text { nitric anhydride } \\
\text { and other higher } \\
\text { peroxy-acylnitrates }\end{array}$ & $\mathrm{X}$ & $\mathrm{X}$ & & \\
\hline HACET & $\begin{array}{l}\text { hydroxyacetone and } \\
\text { other } C_{3} \text {-ketones }\end{array}$ & $\mathrm{X}$ & $\mathrm{X}$ & & \\
\hline NALD & nitrooxy-acetaldehyde & $\mathrm{X}$ & $\mathrm{X}$ & & \\
\hline IEPOX & epoxydiols & & $\mathrm{X}$ & & \\
\hline HPALD & hydroperoxy-aldehydes & & $\mathrm{X}$ & & \\
\hline PACALD & peroxy-acid-aldehydes & & $\mathrm{X}$ & & \\
\hline
\end{tabular}

global 3-D integrations, where reducing computational cost is paramount.

\subsection{Model experiments}

\subsubsection{Box model experiments}

A box model comparison study was performed with the different isoprene schemes to establish any inherent differences in the schemes that do not arise from the complexity present in a global 3-D model. This also allows us to compare the reduced schemes with a more complex scheme, the MCMv3.2 (Jenkin et al., 1997; Archibald et al., 2010b), which is too complex to put into a global 3-D chemistry-climate model. The detailed nature of the MCM lends itself to being a benchmark mechanism against which the others can be compared (e.g. Archibald et al., 2010b). However, the MCM still contains approximations; e.g. many of the rate constants are inferred from other reactions using structure reactivity relationships (SARs, e.g. Kwok and Atkinson, 1995; McGillen et al., 2011), and only four of the six $\mathrm{ISO}_{2}$ isomers are included. Furthermore, many of the recent discoveries such as the isomerisation chemistry of $\mathrm{ISO}_{2}$ and methacrolein are not included.

For our box model comparison, the Kinetic PreProcessor (KPP) solver (Sandu and Sander, 2006) was used, with a model time step of $20 \mathrm{~min}$. The model was set up so that different emissions of $\mathrm{NO}_{x}$ and isoprene were input, allowing us to study how the mechanisms compared over a wide range of $\mathrm{NO}_{x}$-to-isoprene ratios. $\mathrm{NO}_{x}$ emissions between 0.001 and $0.5 \mathrm{mg} \mathrm{N} \mathrm{m}^{-2} \mathrm{~h}^{-1}$ and isoprene emissions between 0.0001 and $6 \mathrm{mg} \mathrm{Cm}^{-2} \mathrm{~h}^{-1}$ were used, with emission rates 
Table 2. Isoprene mechanism for CheT and differences between the CheT mechanism and the CheT2, AQUM and LLSF mechanisms. If a reaction is blank then it is exactly the same as in CheT, such that only the differences are shown. All rate constants $(k)$ are in units of $10^{-14} \mathrm{~cm}^{3}$ molecule ${ }^{-1} \mathrm{~s}^{-1}$. Those species not defined in Table 1 or in the main text are defined here: $\mathrm{HCOOH}-$ formic acid, $\mathrm{H}_{2} \mathrm{O}_{2}-$ hydrogen peroxide, $\mathrm{HCHO}$ - formaldehyde.

\begin{tabular}{|c|c|c|c|c|}
\hline \multirow[t]{2}{*}{ Reactants } & \multicolumn{4}{|c|}{ Products } \\
\hline & CheT & CheT2 & AQUM & LLSF \\
\hline $\mathrm{C}_{5} \mathrm{H}_{8}+\mathrm{OH}$ & $\mathrm{ISO}_{2}$ & & & $2 \mathrm{MeO}_{2}-1.5 \mathrm{OH}$ \\
\hline$k$ & 9990 & & 10100 & \\
\hline $\mathrm{C}_{5} \mathrm{H}_{8}+\mathrm{O}_{3}(1)$ & $\begin{array}{l}1.95 \mathrm{MACR}+1.74 \mathrm{HCHO} \\
+0.3 \mathrm{MACRO}_{2}+0.3 \mathrm{MeCO}_{3}\end{array}$ & & $\begin{array}{l}2 \mathrm{MACR}+1.56 \mathrm{CO} \\
0.44 \mathrm{HCHO}+0.54 \mathrm{HO}_{2}\end{array}$ & $\begin{array}{l}0.87 \mathrm{HCHO}+1.86 \mathrm{MeO}_{2} \\
+0.06 \mathrm{HO}_{2}+0.05 \mathrm{CO}\end{array}$ \\
\hline$k$ & 0.0004 & & 0.0006 & 0.0013 \\
\hline $\mathrm{C}_{5} \mathrm{H}_{8}+\mathrm{O}_{3}(2)$ & $\begin{array}{l}0.24 \mathrm{MeO}_{2}+0.84 \mathrm{HCOOH} \\
+0.42 \mathrm{CO}+0.27 \mathrm{H}_{2} \mathrm{O}_{2}\end{array}$ & & not included & not included \\
\hline$k$ & 0.0004 & & & \\
\hline $\mathrm{C}_{5} \mathrm{H}_{8}+\mathrm{O}_{3}(3)$ & $0.75 \mathrm{HO}_{2}+0.75 \mathrm{OH}$ & & $0.54 \mathrm{OH}$ & not included \\
\hline$k$ & 0.0004 & & 0.0006 & \\
\hline $\mathrm{C}_{5} \mathrm{H}_{8}+\mathrm{NO}_{3}$ & ISON & $\mathrm{ISON}+\mathrm{HO}_{2}$ & $\mathrm{ISON}+\mathrm{HO}_{2}$ & not included \\
\hline$k$ & 69.6 & & 67.8 & \\
\hline $\mathrm{ISO}_{2}+\mathrm{NO}(1)$ & $\begin{array}{l}\mathrm{NO}_{2}+\mathrm{MACR} \\
\mathrm{HCHO}+\mathrm{HO}_{2}\end{array}$ & & $\begin{array}{l}\mathrm{MACR}+\mathrm{NO}_{2} \\
\mathrm{HCHO}+\mathrm{HO}_{2}\end{array}$ & not included \\
\hline$k$ & 813 & & 381 & \\
\hline $\mathrm{ISO}_{2}+\mathrm{NO}(2)$ & ISON & & not included & not included \\
\hline$k$ & 37.5 & 32.6 & & \\
\hline $\mathrm{ISO}_{2}+\mathrm{HO}_{2}$ & ISOOH & & & not included \\
\hline$k$ & 89.4 & & 103 & \\
\hline $\mathrm{ISO}_{2}+\mathrm{ISO}_{2}$ & $\begin{array}{l}2 \mathrm{MACR}+\mathrm{HCHO} \\
+\mathrm{HO}_{2}\end{array}$ & $\begin{array}{l}2 \mathrm{MACR}+2 \mathrm{HCHO} \\
+2 \mathrm{HO}_{2}\end{array}$ & not included & not included \\
\hline$k$ & 200 & & & \\
\hline $\mathrm{ISO}_{2}+\mathrm{MeO}_{2}$ & not included & not included & $\begin{array}{l}\mathrm{MACR}+\mathrm{HCHO} \\
+2 \mathrm{HO}_{2}\end{array}$ & not included \\
\hline$k$ & & & 50 & \\
\hline $\mathrm{ISO}_{2}+\mathrm{N}_{2}$ & not included & $\begin{array}{l}\mathrm{MACR}+\mathrm{HCHO} \\
+\mathrm{OH}\end{array}$ & not included & not included \\
\hline$k$ & & $3.85 \times 10^{10}$ & & \\
\hline $\begin{array}{l}\mathrm{ISO}_{2}+\mathrm{O}_{2} \\
k\end{array}$ & not included & $\begin{array}{l}\mathrm{HPALD}+\mathrm{HO}_{2} \\
2.56 \times 10^{11}\end{array}$ & not included & not included \\
\hline $\mathrm{MACR}+h v$ & $\begin{array}{l}\mathrm{MeCO}_{3}+\mathrm{HCHO} \\
+\mathrm{CO}+\mathrm{HO}_{2}\end{array}$ & & not included & not included \\
\hline $\mathrm{MACR}+\mathrm{OH}(1)$ & $\mathrm{MACRO}_{2}$ & & & not included \\
\hline$k$ & 266 & & 1880 & \\
\hline $\mathrm{MACR}+\mathrm{OH}(2)$ & $\mathrm{MACRO}_{2}$ & & not included & not included \\
\hline$k$ & 510 & & & \\
\hline $\mathrm{MACR}+\mathrm{O}_{3}(1)$ & $\begin{array}{l}1.8 \mathrm{MGLY}+0.9 \mathrm{HCOOH} \\
+0.64 \mathrm{HO}_{2}+0.44 \mathrm{CO}\end{array}$ & & $\begin{array}{l}2 \mathrm{MGLY}+1.52 \mathrm{CO} \\
0.48 \mathrm{HCHO}+0.72 \mathrm{HO}_{2}\end{array}$ & not included \\
\hline$k$ & 0.00013 & & 0.000199 & \\
\hline $\mathrm{MACR}+\mathrm{O}_{3}(2)$ & $0.38 \mathrm{OH}+0.2 \mathrm{MeCO}_{3}$ & & $0.72 \mathrm{OH}$ & not included \\
\hline$k$ & 0.00013 & & 0.000199 & \\
\hline $\mathrm{MACR}+\mathrm{O}_{3}(3)$ & $\begin{array}{l}1.8 \mathrm{MGLY}+0.9 \mathrm{HCOOH} \\
+0.64 \mathrm{HO}_{2}+0.44 \mathrm{CO}\end{array}$ & & not included & not included \\
\hline$k$ & 0.0000305 & & & \\
\hline $\mathrm{MACR}+\mathrm{O}_{3}$ & $0.38 \mathrm{OH}+0.2 \mathrm{MeCO}_{3}$ & & not included & not included \\
\hline$k$ & 0.0000305 & & & \\
\hline MACR dry dep & included & & not included & not included \\
\hline $\mathrm{MACRO}_{2}+\mathrm{NO}_{2}+\mathrm{M}$ & MPAN & & not included & not included \\
\hline & KFPAN & KFPAN*0.107 & & \\
\hline $\mathrm{MACRO}_{2}+\mathrm{NO}(1)$ & $\begin{array}{l}2 \mathrm{NO}_{2}+0.5 \mathrm{MeCO}_{3} \\
+0.5 \mathrm{HACET}+0.5 \mathrm{CO}\end{array}$ & & $\begin{array}{l}\mathrm{NO}_{2}+\mathrm{HO}_{2} \\
\mathrm{HCHO}+\mathrm{MGLY}\end{array}$ & not included \\
\hline$k$ & 425 & 452 & 837 & \\
\hline $\mathrm{MACRO}_{2}+\mathrm{NO}(2)$ & $\begin{array}{l}\mathrm{MGLY}+1.5 \mathrm{HCHO} \\
+1.5 \mathrm{HO}_{2}\end{array}$ & & not included & not included \\
\hline$k$ & 425 & 452 & & \\
\hline $\mathrm{MACRO}_{2}+\mathrm{HO}_{2}$ & MACROOH & & & not included \\
\hline$k$ & 1428 & & 1479 & \\
\hline
\end{tabular}


Table 2. Continued.

\begin{tabular}{|c|c|c|c|c|}
\hline \multirow[t]{2}{*}{ Reactants } & \multicolumn{4}{|c|}{ Products } \\
\hline & CheT & CheT2 & AQUM & LLSF \\
\hline $\mathrm{MACRO}_{2}+\mathrm{MACRO}_{2}(1)$ & $\begin{array}{l}2 \mathrm{HACET}+2 \mathrm{MGLY} \\
+\mathrm{HCHO}+\mathrm{CO}\end{array}$ & & not included & not included \\
\hline$k$ & 100 & & & \\
\hline$\underset{k}{\mathrm{MACRO}_{2}+\mathrm{MACRO}_{2}(2)}$ & $\begin{array}{l}2 \mathrm{HO}_{2} \\
100\end{array}$ & & not included & not included \\
\hline $\mathrm{ISON}+h v$ & $\begin{array}{l}\mathrm{NO}_{2}+\mathrm{MACR} \\
+\mathrm{HCHO}+\mathrm{HO}_{2}\end{array}$ & & not included & not included \\
\hline$k$ & 1300 & 3340 & & \\
\hline $\mathrm{ISON}+\mathrm{OH}(1)$ & HACET + NALD & $\begin{array}{l}0.78 \mathrm{HACET}+0.78 \mathrm{NALD} \\
+0.78 \mathrm{HO}_{2}\end{array}$ & $\mathrm{MACR}+\mathrm{NO}_{2}$ & not included \\
\hline$k$ & 1300 & 1940 & 4160 & \\
\hline $\mathrm{ISON}+\mathrm{OH}(2)$ & not included & $\begin{array}{l}0.44 \mathrm{NO}_{2}+0.44 \mathrm{MACR} \\
+0.44 \mathrm{HCHO}\end{array}$ & not included & not included \\
\hline$k$ & & 0.00313 & & \\
\hline$\underset{k}{\mathrm{ISON}}+\mathrm{O}_{3}(1)$ & not included & $\begin{array}{l}\mathrm{NALD}+\mathrm{OH} \\
0.00607\end{array}$ & & \\
\hline $\mathrm{ISON}+\mathrm{O}_{3}(2)$ & not included & $\begin{array}{l}\mathrm{MACR}+\mathrm{HCHO} \\
\mathrm{NO}_{2}\end{array}$ & & \\
\hline$k$ & & 0.00313 & & \\
\hline ISON wet dep & included & & & not included \\
\hline ISON dry dep & included & & not included & not included \\
\hline $\mathrm{HCOOH}+\mathrm{OH}$ & $\mathrm{HO}_{2}$ & & not included & not included \\
\hline$k$ & 45 & & & \\
\hline HCOOH wet dep & included & & not included & not included \\
\hline HCOOH dry dep & included & & not included & not included \\
\hline $\mathrm{ISOOH}+h v$ & $\mathrm{OH}+\mathrm{MACR}$ & & $\mathrm{OH}+\mathrm{MACR}$ & not included \\
\hline $\mathrm{ISOOH}+\mathrm{OH}(1)$ & $\mathrm{MACR}+\mathrm{OH}$ & & & \\
\hline$k$ & 10000 & 894 & & \\
\hline $\begin{array}{l}\mathrm{ISOOH}+\mathrm{OH}(2) \\
k\end{array}$ & not included & $\begin{array}{l}\text { IEPOX + OH } \\
8064\end{array}$ & & \\
\hline ISOOH wet dep & included & & not included & not included \\
\hline ISOOH dry dep & included & & not included & not included \\
\hline $\mathrm{MPAN}+h v$ & & & not included & not included \\
\hline $\mathrm{MPAN}+\mathrm{M}$ & $\mathrm{MACRO}_{2}+\mathrm{NO}_{2}$ & & not included & not included \\
\hline $\mathrm{MPAN}+\mathrm{OH}$ & $\mathrm{HACET}+\mathrm{NO}_{2}$ & & not included & not included \\
\hline$k$ & 2900 & & & \\
\hline MPAN dry dep & included & & not included & not included \\
\hline $\mathrm{HACET}+h v$ & $\begin{array}{l}\mathrm{MeCO}_{3}+\mathrm{HCHO} \\
+\mathrm{HO}_{2}\end{array}$ & & not included & not included \\
\hline $\begin{array}{l}\mathrm{HACET}+\mathrm{OH} \\
k\end{array}$ & $\begin{array}{l}\mathrm{MGLY}+\mathrm{HO}_{2} \\
300\end{array}$ & 445 & not included & not included \\
\hline HACET wet dep & included & & not included & not included \\
\hline HACET dry dep & included & & not included & not included \\
\hline $\mathrm{MACROOH}+h v(1)$ & $2 \mathrm{OH}+2 \mathrm{HO}_{2}$ & & $\begin{array}{l}\mathrm{OH}+\mathrm{MGLY} \\
+\mathrm{HCHO}+\mathrm{HO}_{2}\end{array}$ & not included \\
\hline $\mathrm{MACROOH}+h v(2)$ & $\begin{array}{l}\text { HACET + CO } \\
+ \text { MGLY + HCHO }\end{array}$ & & not included & not included \\
\hline $\mathrm{MACROOH}+\mathrm{OH}$ & $\mathrm{MACRO}_{2}$ & & $\begin{array}{l}\mathrm{MGLY}+\mathrm{HCHO} \\
+\mathrm{OH}\end{array}$ & not included \\
\hline$k$ & 3000 & & 5770 & \\
\hline MACROOH wet dep & included & & & not included \\
\hline MACROOH dry dep & included & & & not included \\
\hline $\mathrm{NALD}+h v$ & $\mathrm{HCHO}+\mathrm{CO}$ & & not included & not included \\
\hline & $\mathrm{NO}_{2}+\mathrm{HO}_{2}$ & & not included & not included \\
\hline
\end{tabular}


Table 2. Continued.

\begin{tabular}{|c|c|c|c|c|}
\hline \multirow{2}{*}{ Reactants } & \multicolumn{4}{|c|}{ Products } \\
\hline & CheT & CheT2 & AQUM & LLSF \\
\hline $\mathrm{NALD}+\mathrm{OH}$ & $\begin{array}{l}\mathrm{HCHO}+\mathrm{CO} \\
+\mathrm{NO}_{2}\end{array}$ & & not included & not included \\
\hline$k$ & 1500 & 155 & & \\
\hline NALD dry dep & included & & not included & not included \\
\hline $\mathrm{MACRO}_{2}+\mathrm{MeO}_{2}$ & not included & & $\begin{array}{l}\mathrm{MGLY}+\mathrm{HCHO} \\
2 \mathrm{HO}_{2}\end{array}$ & \\
\hline$k$ & & & 200 & \\
\hline $\mathrm{HPALD}+h v$ & not included & $\begin{array}{l}\text { PACALD }+\mathrm{HO}_{2} \\
+\mathrm{OH}\end{array}$ & & \\
\hline $\mathrm{HPALD}+\mathrm{OH}$ & not included & $\begin{array}{l}\mathrm{MGLY}+\mathrm{CO} \\
+\mathrm{HCHO}+\mathrm{OH}\end{array}$ & & \\
\hline$k$ & & 7610 & & \\
\hline $\begin{array}{l}\mathrm{IEPOX}+\mathrm{OH} \\
k\end{array}$ & not included & $\begin{array}{l}\mathrm{MACRO}_{2} \\
913\end{array}$ & & \\
\hline IEPOX dry dep & not included & included & & \\
\hline IEPOX wet dep & not included & included & & \\
\hline PACALD $+h v$ & not included & $\begin{array}{l}\mathrm{CO}+\mathrm{HO}_{2} \\
+\mathrm{MGLY}+\mathrm{OH}\end{array}$ & & \\
\hline
\end{tabular}

being constant for the duration of a given model run. Atmospheric pressure $\left(1 \times 10^{5} \mathrm{~Pa}\right)$ and temperature $(298 \mathrm{~K})$ were kept constant, and the amount of light varied through the day as in a grid cell at $14^{\circ}$ latitude on Julian day 172 (solar declination angle $=23.44^{\circ}$ ). To ensure that differences in the oxidation chemistry were not due to differences in photolysis between the mechanisms, the MCM photolysis parameterisation was used in all cases. Details of how photolysis coefficients are calculated using this parameterisation are given in Jenkin et al. (1997). The model was initialised with $30 \mathrm{ppb} \mathrm{O}_{3}, 1820 \mathrm{ppb} \mathrm{CH}_{4}, 102 \mathrm{ppbCO}$, and run with a fixed amount of $\mathrm{H}_{2} \mathrm{O}(50 \%)$.

The box model does not include any advection or deposition processes, and, as such, $\mathrm{O}_{3}$ values are likely to be higher than those measured in the field or calculated in UM-UKCA. Other consequences of including emissions but not removal pathways are that steady state will never be reached and longlived reservoir species will accumulate. For example, $\mathrm{OH}$ could be modified by accumulation of $\mathrm{H}_{2} \mathrm{O}_{2}$ via $\mathrm{OH}+\mathrm{H}_{2} \mathrm{O}_{2}$. To minimise such effects on oxidant fields, a relatively short run length of 3 days for the simulations was chosen. In all simulations, the maximum $\mathrm{O}_{3}$ value on the third day was used to provide a consistent point of comparison between mechanisms. The results of the box model comparison are given in Sect. 3 .

\subsubsection{Global perturbation experiments}

To investigate the influence of variations in the isoprene mechanism on potential changes in tropospheric $\mathrm{O}_{3}$ over the 21 st century, a global chemistry-climate model (the UK Met Office Unified Model coupled to the UK Chemistry and Aerosol model, UM-UKCA) was used, as specified in Squire et al. (2014). For each mechanism investigated, a present-day
(2000) integration was conducted, following the model setup described for the BASE run in Squire et al. (2014). Then, for each mechanism four future (2095) integrations were conducted to investigate (1) CC, climate change only, (2) IC, isoprene emission change with climate, (3) AC, anthropogenic emission change, and (4) LC, land use change, with each integration set up as described in Squire et al. (2014). The effect of mechanistic changes on the $\mathrm{O}_{3}$ response to including the $\mathrm{CO}_{2}$ inhibition of isoprene emissions was not investigated in this study. It should also be noted that with the change in land use, we assume no change in $\mathrm{NO}_{x}$ emissions.

For $\mathrm{CC}$, all parameters, including isoprene emissions, remained as in the present day BASE run except sea surface temperatures, sea ice concentrations and greenhouse gas concentrations. In IC, isoprene emissions were allowed to vary with a scenario of future climate change. This led to globally higher isoprene emissions (545 $\mathrm{Tg} \mathrm{Cyr}^{-1}$ ) than in the BASE run (467 $\mathrm{TgC} \mathrm{yr}^{-1}$ ), largely due to the effect of extended $\mathrm{CO}_{2}$ fertilisation of the biosphere under the elevated $\mathrm{CO}_{2}$ levels. AC was characterised by stringent emission cuts across much of the Northern Hemispheric developed regions, leading to lower $\mathrm{NO}_{x}$ levels there. For LC, we used a scenario of future cropland expansion that is dominated by the replacement of tropical broadleaf trees with crops (see Squire et al. (2014) for details). As the crops emit less isoprene than broadleaf trees (Guenther et al., 2006; Lathiere et al., 2010), this causes a decrease in isoprene emissions $\left(190 \mathrm{TgC}^{-1}\right.$ globally).

\section{Mechanism intercomparison with a box model}

In this section we discuss the results of the simulations we performed to assess the performance of the isoprene mecha- 


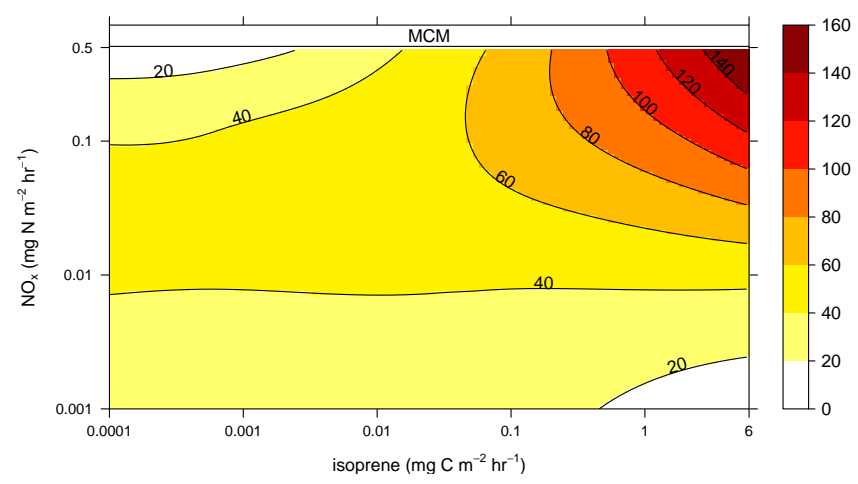

Figure 1. $\mathrm{O}_{3}(\mathrm{ppb})$ isopleth plot as a function of $\mathrm{NO}_{x}$ and isoprene emissions for the Master Chemical Mechanism (MCMv3.2). This was created from a series of box model runs.

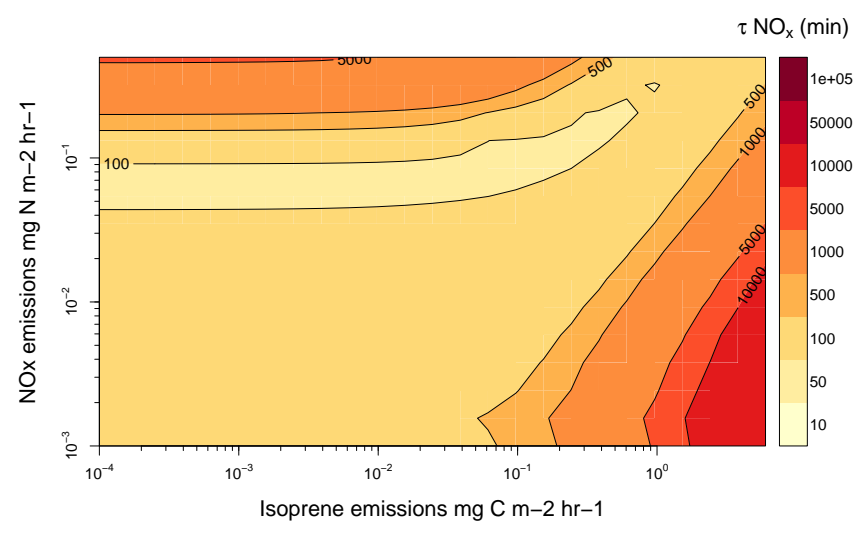

Figure 2. $\tau \mathrm{NO}_{x}(\mathrm{~min})$ isopleth plot as a function of $\mathrm{NO}_{x}$ and isoprene emissions for the Master Chemical Mechanism (MCMv3.2). This was created from a series of box model runs.

nisms we investigated in UKCA using a simple box model. The simulations we performed were aimed at understanding how mechanistic assumptions affected the simulation of $\mathrm{O}_{3}$ by comparing the results of the reduced mechanisms to the MCM.

As discussed in Sect. 1, the inherent assumptions regarding mechanism reduction (Jeffries et al., 1992), and specifically the omission of unique isoprene oxidation products, may lead to large discrepancies for simulated $\mathrm{O}_{3}$ between the mechanisms. Here we hypothesise that assumptions about the sequestration of $\mathrm{HO}_{x}$ (via organic hydroperoxides $\mathrm{ROOH}$ ) and $\mathrm{NO}_{x}$ (via organic nitrates $\mathrm{RONO}_{2}$ ) are a key cause of inter-mechanism variability and lead to changes in the abundance and hence lifetime of $\mathrm{NO}_{x}$.

To test this hypothesis, for each mechanism, box model runs were performed at a series of different $\mathrm{NO}_{x}$ and isoprene emission rates, so that an $\mathrm{O}_{3}$ isopleth plot could be constructed, similar to those found in Dodge (1977) and Sillman and $\mathrm{He}$ (2002). In general, all mechanisms produce the same overall behaviour of increasing $\mathrm{O}_{3}$ with increasing isoprene and $\mathrm{NO}_{x}$ emissions. These general features can be seen

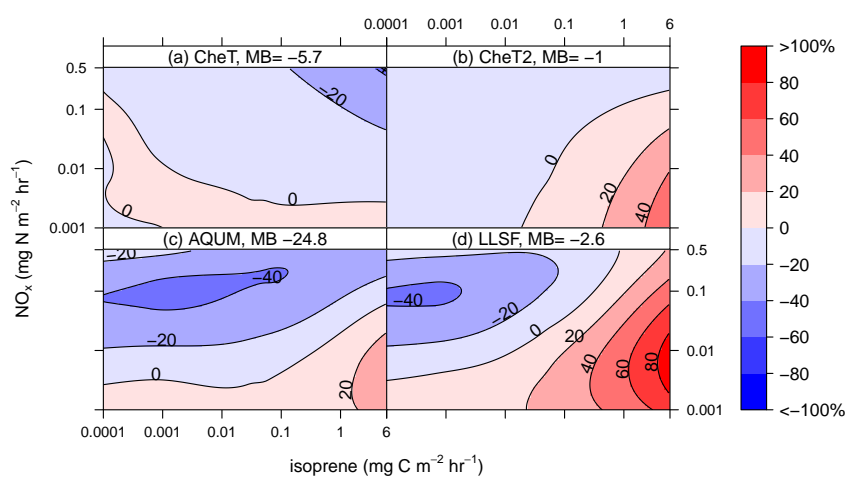

Figure 3. $\mathrm{O}_{3}$ (percentage difference from the MCM, Fig. 1) isopleth plot as a function of $\mathrm{NO}_{x}$ and isoprene emissions for different isoprene chemical mechanisms. Also quoted for each plot is the mean bias (MB) from the MCM.

in Fig. 1 for the MCM. When both $\mathrm{NO}_{x}$ and isoprene are low, $\mathrm{O}_{3}$ stays around the initial concentration ( $\left.30 \mathrm{ppb}\right)$. As emission rates of both $\mathrm{O}_{3}$ precursors increase, $\mathrm{O}_{3}$ increases reaching a maximum of 140-160 ppb at the highest emission rates used $\left(0.5 \mathrm{mg} \mathrm{N} \mathrm{m}^{-2} \mathrm{~h}^{-1}\right.$ of $\mathrm{NO}_{x}$ and $6 \mathrm{mg} \mathrm{Cm}^{-2} \mathrm{~h}^{-1}$ of isoprene - top right-hand corner). When isoprene emissions are low and $\mathrm{NO}_{x}$ emissions are high (top left-hand corner) net $\mathrm{O}_{3}$ destruction occurs that is consistent with high nitric acid formation $\left(\mathrm{O}_{x}\right.$ loss via $\left.\mathrm{NO}_{2}+\mathrm{OH}\right)$. When isoprene emissions are high and $\mathrm{NO}_{x}$ emissions are low, as in a tropical rainforest, (lower right-hand corner) net $\mathrm{O}_{3}$ destruction occurs as is consistent with high levels isoprene ozonolysis and loss of $\mathrm{O}_{3}$ via reactions with $\mathrm{HO}_{x}$. Considering that the box model in some cases does not reach equilibrium, the precise numbers reported here (e.g. 140-160 ppb) are not of significance to the real world where removal processes (i.e. deposition of intermediate compounds and $\mathrm{O}_{3}$ and $\mathrm{NO}_{x}$ ) exist. The overall behaviour of $\mathrm{O}_{3}$ in Fig. 1 is shown to be related to the overall behaviour of the $\mathrm{NO}_{x}$ lifetime (Fig. 2), defined using Equation 1 from Browne and Cohen (2012). Fig. 2 shows that the $\mathrm{NO}_{x}$ lifetime varies by over 2 orders of magnitude over the range of $\mathrm{NO}_{x}$ and isoprene emissions the simulations covered. A general feature of Fig. 2 is that the $\mathrm{NO}_{x}$ lifetime shows a degree of anticorrelation with the $\mathrm{O}_{3}$ mixing ratios simulated. Regions of the $\mathrm{O}_{3}$ isopleth where net $\mathrm{O}_{3}$ destruction occurs coincide with regions where the $\mathrm{NO}_{x}$ lifetime is greatest. The key cause of this is a reduction in the abundance of $\mathrm{OH}$.

Our main focus is on the comparison of the reduced mechanisms with the MCM for the simulated $\mathrm{O}_{3}$ mixing ratios and $\mathrm{NO}_{x}$ lifetimes. Figures 3 and 4 show the differences in the $\mathrm{O}_{3}$ and $\mathrm{NO}_{x}$ lifetimes simulated using the reduced mechanisms relative to the MCM. These differences provide us with useful information about variations in chemical oxidation between the schemes, which may be used to help diagnose the impact of isoprene mechanism differences in the more complex context of the global model experiments (Sect. 4). 


\subsection{LLSF}

LLSF is the most simplistic scheme with no unique species used to represent the chemistry of isoprene, beyond those used to describe the oxidation of methane. Thus, there is only a small amount of $\mathrm{NO}_{x}$ locked up in methyl nitrate formation (reflecting the small yield of methyl nitrate production) and $\mathrm{HO}_{x}$ is efficiently sequestered into organic hydroperoxides (reflecting the slow rates of reactivity of methyl hydroperoxide). Figure 3d shows that using LLSF results in the highest biases in $\mathrm{O}_{3}$ compared to the MCM of all the mechanisms considered. Under low- $\mathrm{NO}_{x}$ high-isoprene emissions, LLSF is biased high by up to $\sim 80 \%$. Because the reaction between $\mathrm{MeO}_{2}$ and $\mathrm{HO}_{2}$ is slower than for the major isoprene-derived peroxy radicals in the MCM, mixing ratios of peroxy radicals are found to be higher in this region, and the enhanced rate of $\mathrm{RO}_{2}+\mathrm{NO}$ leads to high $\mathrm{O}_{3}$. This is consistent with the differences in the $\mathrm{NO}_{x}$ lifetime (Fig. 4d) which show that under these conditions, the LLSF mechanism simulates an overall shorter $\mathrm{NO}_{x}$ lifetime. This shorter lifetime is reflected across most of the VOC: $\mathrm{NO}_{x}$ emission space with the exception of high- $\mathrm{NO}_{x}$ emissions, where there is better agreement with the MCM (biases $\sim 10 \%$ ). A band of low-bias in $\mathrm{O}_{3}$ (Fig. 3d) is correlated with a band of high-bias in $\mathrm{NO}_{x}$ lifetime (Fig. 4d) under a range of low isoprene emissions and moderately high $\mathrm{NO}_{x}$ emissions. Both of these features are consistent with the parameterised instantaneous loss of two $\mathrm{OH}$ for the isoprene $+\mathrm{OH}$ reaction in LLSF. With LLSF, the low bias at low isoprene emissions and high bias at high isoprene emissions largely cancel each other out, leading to a small overall $\mathrm{MB}(-2.6 \%)$ for $\mathrm{O}_{3}$ with respect to the MCM (Fig. 3d). Despite a small overall bias, the majority of the regions where isoprene chemistry is known to be important for the $\mathrm{O}_{3}$ budget are the regions where this mechanism shows greatest bias.

\subsection{AQUM}

As discussed in Sec. 2.1, AQUM was developed for representing the oxidation of isoprene in the context of simulating regional air quality. As such AQUM does not account for the formation of organic nitrates, other than from the reaction of isoprene with $\mathrm{NO}_{3}$. Under low- $\mathrm{NO}_{x}$ high-isoprene emissions, AQUM is biased high by $\sim 20 \%$ (Fig. 3c). The figure shows that there is a band of large negative MB $(-25 \%)$ in $\mathrm{O}_{3}$, compared to the MCM, under $\mathrm{NO}_{x}$ emissions of $0.01-$ $0.1 \mathrm{mg} \mathrm{N} \mathrm{m}^{-2} \mathrm{~h}^{-1}$. There is very little correlation between the biases in $\mathrm{O}_{3}$ and biases in the $\mathrm{NO}_{x}$ lifetime (Fig. 4c) under these emissions. In regions of high-isoprene high- $\mathrm{NO}_{x}$ emissions AQUM simulates much greater values of $\mathrm{NO}_{x}$ lifetime than the MCM, consistent with a reduction in the abundance of $\mathrm{NO}_{x}$ (Browne and Cohen, 2012) and a reduction in $\mathrm{OH}$. Whilst the reduction in the abundance of $\mathrm{NO}_{x}$, as evidenced by the increase in $\mathrm{NO}_{x}$ lifetime, is consistent with a reduction in the potential for producing $\mathrm{O}_{3}$, it cannot be as-

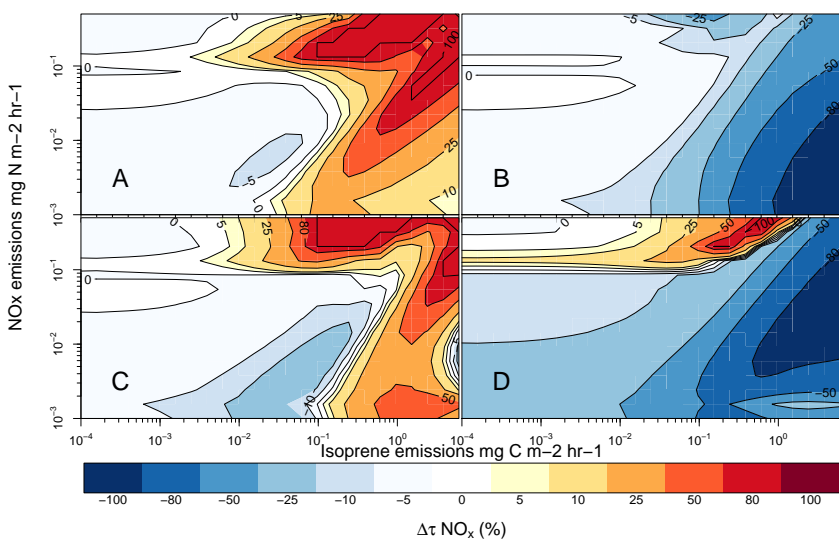

Figure 4. $\tau \mathrm{NO}_{x}$ (percentage difference from the MCM, Fig. 2) isopleth plot as a function of $\mathrm{NO}_{x}$ and isoprene emissions for different isoprene chemical mechanisms: (A) CheT, (B) CheT2, (C) AQUM, (D) LLSF.

cribed to sequestration of $\mathrm{NO}_{x}$ in organic nitrates and the attribution of the origin of this behaviour lies beyond the scope of this investigation.

\subsection{CheT}

CheT, which is based on the MIM (Pöschl et al., 2000) was developed for global-scale modelling studies of atmospheric chemistry. As with AQUM, it accounts for the formation of isoprene nitrates produced via $\mathrm{NO}_{3}$ chemistry but also includes the generation of isoprene nitrates from the $\mathrm{OH}$ initiated oxidation (the primary route for isoprene oxidation). Fig. 3a shows the bias in $\mathrm{O}_{3}$ simulated using CheT compared with the MCM. The bias in $\mathrm{O}_{3}$ is generally within $\pm 20 \%$ of the MCM over all the emissions of isoprene and $\mathrm{NO}_{x}$ we investigated. Under high- $\mathrm{NO}_{x}$ and high-isoprene emissions, the bias is higher, with CheT simulating up to $40 \%$ less $\mathrm{O}_{3}$ than the MCM. Under these conditions CheT also simulates an increase of the $\mathrm{NO}_{x}$ lifetime, consistent with a reduction in the abundance of $\mathrm{NO}_{x}$ (Fig. 4a). Overall the mean bias (MB) is $-5.7 \%$, indicating a weak negative bias compared to the MCM. This result is consistent with the work of Archibald et al. (2010b) who showed that the CheT scheme (UKCA in their runs) simulated lower levels of $\mathrm{O}_{3}$ than the MCMv3.1.

\subsection{CheT2}

The last reduced mechanism that was tested in the box model was CheT2. CheT2 is based on CheT but includes recent updates to the oxidation of isoprene including the formation of IEPOX (Paulot et al., 2009) and modifications to the treatment of isoprene nitrates, allowing regeneration of $\mathrm{NO}_{x}$ and formation of multigeneration nitrates. Figure $3 b$ shows that the low bias in $\mathrm{O}_{3}$ simulated at high $\mathrm{O}_{3}$ precursor emissions is much less pronounced in CheT2 than in CheT, being 


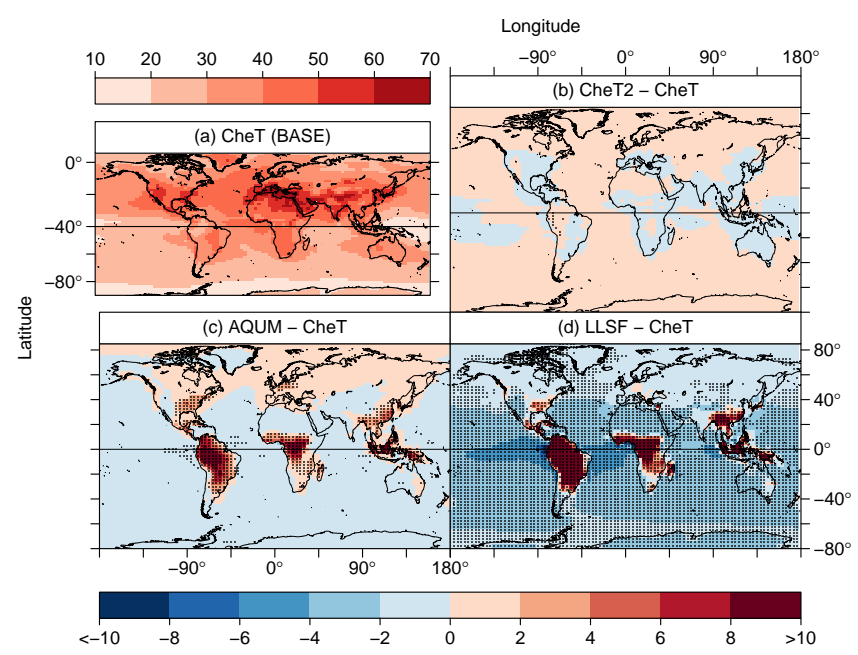

Figure 5. Difference in the present-day (2000, BASE) 5-year mean near-surface $(<720 \mathrm{~m}) \mathrm{O}_{3}(\mathrm{ppb})$ between CheT isoprene chemistry and other isoprene chemical mechanisms. The stippling indicates where the difference is significant at the $5 \%$ level (greater than \pm 2.5 $x$ the standard error).

within $\pm 20 \%$ of the MCM. This is consistent with the lower rate of MPAN formation in CheT2 compared to CheT, meaning that more $\mathrm{NO}_{x}$ is available for $\mathrm{O}_{3}$ formation. This is also observed in the comparison of the $\mathrm{NO}_{x}$ lifetime. Figure $4 \mathrm{~b}$ highlights that there is overall a shorter $\mathrm{NO}_{x}$ lifetime (reduction of $50 \%$ ) across the range of isoprene and $\mathrm{NO}_{x}$ emissions simulated. Under high-isoprene low- $\mathrm{NO}_{x}$ conditions, the effect of the addition of the $\mathrm{ISO}_{2} \mathrm{HO}_{x}$ regeneration pathways present in CheT2 (the Peeters mechanism, Peeters et al., 2009 ) is seen. These were not included in the MCMv3.2, and they serve to enhance $\mathrm{HO}_{x}$, and decrease $\mathrm{NO}_{x}$, similar to LLSF. This finding is consistent with the enhanced $\mathrm{O}_{3}$ seen in Archibald et al. (2011) when CheT (UKCA in their work) was run with inclusion of the Peeters mechanism. Overall the MB of CheT2 with respect to the MCM is lower $(-1 \%)$ than for CheT $(-5.7 \%)$.

\subsection{Summary of box model results}

These box modelling results show that biases in simulated $\mathrm{O}_{3}$ are related to the treatments of organic nitrate and organic hydroperoxide chemistry, and to the simulated abundance of $\mathrm{NO}_{x}$ (and its lifetime). The box modelling allows us to examine the effect of the complexity of the chemical processes included and we have shown that we are able to begin to understand the effects of mechanistic differences. It is clear that conclusions drawn solely on the basis of e.g. $\mathrm{NO}_{x}$ lifetime are necessarily incomplete, e.g. in the case of the AQUM biases, and that a detailed analysis of individual reaction fluxes is required to quantitatively understand the origin of biases over the range of emissions used in global model simulations. However, we emphasise that we have not attempted to perform a systematic study on the isoprene oxidation mechanism. A more rigorous approach would be to examine the individual effects of omissions of mechanistic pathways through one-at-a-time sensitivity tests using one base mechanism, for example the MCM. This is far beyond the scope of our study, which aims to qualify the role of uncertainty in the chemistry vs. the uncertainty in forcings (e.g. emissions) as drivers for the uncertainty of global simulations of $\mathrm{O}_{3}$. Rather, we aim to link the results from the box model simulations with the global model results (Sect. 4) to provide insight into the behaviour of the isoprene- $-\mathrm{NO}_{x}-\mathrm{O}_{3}$ system. In the following section we will discuss the results of simulations with a global chemistry-climate model where each of the reduced mechanisms is used to assess the impact of using different chemical mechanisms on simulations of climate, land use and emission changes.

\section{Present-day mechanism intercomparison with a global model}

Using the four reduced schemes, global simulations of the present-day atmosphere were conducted. Figure 5a shows near-surface $\mathrm{O}_{3}$ for the present day using the CheT isoprene scheme. Figure 5b-d illustrates the change in this $\mathrm{O}_{3}$ caused by the use of different isoprene chemical schemes. All schemes simulate a present-day tropospheric $\mathrm{O}_{3}$ burden that is within 1 standard deviation of the model ensemble mean from the ACCENT study ( $344 \pm 39 \mathrm{Tg}$ ) (Stevenson et al., 2006). As may be expected from a comparison of isoprene chemical mechanisms, the largest differences between the schemes occur where isoprene emissions are highest (tropical regions and the southeast USA). In these regions (mean isoprene emissions $>0.1 \mathrm{mg} \mathrm{C} \mathrm{m}^{-2} \mathrm{~h}^{-1}$ ), the mean surface $\mathrm{O}_{3}$ for CheT is $41 \mathrm{ppb}$, whilst for AQUM and LLSF the values are higher $-46 \mathrm{ppb}(+11 \%)$ and $50 \mathrm{ppb}(+18 \%)$ respectively. In some places (e.g. Amazonia, Central Africa), this equates to surface $\mathrm{O}_{3}$ that is at least $10 \mathrm{ppb}$ higher than with CheT. By comparison, surface $\mathrm{O}_{3}$ in CheT2 is very similar to that of CheT, even in the high isoprene emitting regions.

The regions of high isoprene emissions, where the largest differences between the mechanisms are calculated, are generally situated away from areas of intense anthropogenic activity. As a result, these areas tend to have low $\mathrm{NO}_{x}$ emissions. To understand the changes occurring in this low- $\mathrm{NO}_{x}$ high-isoprene regime, Table 3 gives the mean $\mathrm{O}_{x}$ budget fluxes for near-surface (below $720 \mathrm{~m}$ ) grid cells with monthly mean $\mathrm{NO}_{x}$ emissions less than $0.03 \mathrm{mg} \mathrm{N} \mathrm{m}^{-2} \mathrm{~h}^{-1}$ and monthly mean isoprene emissions greater than $0.1 \mathrm{mg} \mathrm{C} \mathrm{m}^{-2} \mathrm{~h}^{-1}$ (roughly matching the bottom right-hand quarter of Fig. 1). Here we define $\mathrm{O}_{x}$ as $\mathrm{O}^{3} \mathrm{P}+\mathrm{O}^{1} \mathrm{D}+\mathrm{O}_{3}+2 \times \mathrm{NO}_{3}+\mathrm{NO}_{2}+3 \times$ dinitrogen pentoxide $\left(\mathrm{N}_{2} \mathrm{O}_{5}\right)+$ nitric acid $\left(\mathrm{HNO}_{3}\right)+$ peroxynitric acid $\left(\mathrm{HNO}_{4}\right)+\mathrm{PAN}+$ peroxypropionyl nitrate $($ PPAN $)+$ MPAN. Figure 6 shows geographical loca- 
Table 3. Near-surface (below $720 \mathrm{~m}$ ) mean $\mathrm{O}_{x}$ budget fluxes $\left(\mathrm{mol} \mathrm{gc}^{-1} \mathrm{~s}^{-1}\right.$ ) for regions with high isoprene emissions (greater than $0.1 \mathrm{mg} \mathrm{C} \mathrm{m}^{-2} \mathrm{~h}^{-1}$ ) and low $\mathrm{NO}_{x}$ emissions (less than $0.03 \mathrm{mg} \mathrm{N} \mathrm{m}^{-2} \mathrm{~h}^{-1}$ ). Values from the BASE run are given. Also given are the differences caused by climate change (CC) and land use change (LC). See Fig. 6 for which grid cells were used to calculate the values in this table. $\Sigma \mathrm{RO}_{2}=\mathrm{HO}_{2}+\mathrm{MeO}_{2}+\mathrm{RO}_{2}$.

\begin{tabular}{|c|c|c|c|c|c|c|c|c|c|c|c|c|}
\hline \multirow[t]{2}{*}{ Flux } & \multicolumn{3}{|c|}{ CheT } & \multicolumn{3}{|c|}{ CheT2 } & \multicolumn{3}{|c|}{ AQUM } & \multicolumn{3}{|c|}{ LLSF } \\
\hline & BASE & $\mathrm{CC}$ & LC & BASE & $\mathrm{CC}$ & LC & BASE & $\mathrm{CC}$ & LC & BASE & $\mathrm{CC}$ & LC \\
\hline $\mathrm{HO}_{2}+\mathrm{NO}$ & 31 & +4.6 & +3.3 & 32 & +4.4 & +3.2 & 55 & +7.8 & -2.2 & 97 & -1.8 & -16 \\
\hline $\mathrm{MeO}_{2}+\mathrm{NO}$ & 12 & +2.1 & +1.6 & 11.5 & +2.0 & +1.8 & 21 & +3.5 & -0.2 & 100 & -3.2 & -30 \\
\hline $\mathrm{RO}_{2}+\mathrm{NO}$ & 31 & +3.4 & -7.0 & 29 & +2.9 & -6.7 & 51 & +4.0 & -14 & 2.0 & +0.1 & +0.7 \\
\hline $\mathrm{OH}+\mathrm{RCOOH}$ & 0.0 & 0.0 & 0.0 & 0.0 & 0.0 & 0.0 & 0.0 & 0.1 & 0.0 & 0.1 & 0.0 & 0.0 \\
\hline $\mathrm{RONO}_{2}+\mathrm{OH}$ & 0.3 & +0.1 & +0.1 & 0.3 & +0.1 & 0.0 & 1.4 & +0.2 & -0.3 & 0.0 & 0.0 & 0.0 \\
\hline $\mathrm{RONO}_{2}+\mathrm{h} v$ & 0.1 & 0.0 & 0.0 & 0.4 & 0.0 & -0.1 & 0.0 & 0.0 & 0.0 & 0.0 & 0.0 & 0.0 \\
\hline $\mathrm{O}^{1} \mathrm{D}+\mathrm{H}_{2} \mathrm{O}$ & 29 & +2.6 & +1.3 & 29 & +2.4 & +1.1 & 35 & +3.4 & -0.7 & 43 & +1.9 & -4.2 \\
\hline Minor loss rxns & 0.0 & 0.0 & 0.0 & 0.0 & 0.0 & 0.0 & 0.0 & 0.0 & 0.0 & 0.0 & 0.0 & 0.0 \\
\hline $\mathrm{HO}_{2}+\mathrm{O}_{3}$ & 8.2 & +0.8 & -0.1 & 9.0 & +0.8 & -0.2 & 13 & +1.6 & -1.3 & 19 & -0.3 & -4.5 \\
\hline $\mathrm{OH}+\mathrm{O}_{3}$ & 1.4 & +0.2 & +0.9 & 1.5 & +0.2 & +0.9 & 2.3 & +0.5 & +0.9 & 2.8 & +0.2 & +0.9 \\
\hline $\mathrm{O}_{3}+$ alkene & 20 & -2.6 & -11 & 19 & -2.7 & -10 & 19 & -3.0 & -11 & 18 & -3.4 & -12 \\
\hline $\mathrm{N}_{2} \mathrm{O}_{5}+\mathrm{H}_{2} \mathrm{O}$ & 0.0 & 0.0 & 0.0 & 0.0 & 0.0 & 0.0 & 0.0 & 0.0 & 0.0 & 0.2 & 0.0 & 0.0 \\
\hline $\mathrm{NO}_{3}$ Loss & 2.9 & +0.5 & -0.2 & 3.0 & +0.5 & -0.3 & 4.7 & +0.5 & -1.1 & 3.8 & 0.0 & -1.1 \\
\hline $\mathrm{NO}_{\mathrm{y}}$ Wet Dep & 0.7 & 0.0 & +0.2 & 0.7 & 0.0 & +0.2 & 0.9 & +0.1 & +0.2 & 1.4 & -0.1 & -1.1 \\
\hline$\Sigma \mathrm{RO}_{2}+\mathrm{NO}$ & 74 & +10 & -2.1 & 73 & +9.3 & -1.5 & 130 & +15 & -16 & 199 & -4.9 & -45 \\
\hline Tot. Chem Prod & 74 & +10 & -2.0 & 74 & +9.4 & -1.7 & 130 & +16 & -17 & 200 & -4.9 & -45 \\
\hline Tot. Chem Loss & 62 & +1.6 & -8.7 & 62 & +1.3 & -8.4 & 75 & +3.0 & -13 & 89 & -1.6 & -20 \\
\hline Net Chem & 13 & +8.6 & +6.7 & 12 & +8.0 & +6.7 & 53 & +13 & -4.0 & 110 & -3.2 & -24 \\
\hline $\mathrm{O}_{3}$ Dry Dep & 330 & +14 & +2.4 & 330 & +12 & -0.2 & 390 & +18 & -23 & 490 & -6.1 & -74 \\
\hline $\mathrm{NO}_{\mathrm{y}}$ Dry Dep & 10 & 0.0 & -0.1 & 10 & +0.1 & 0.0 & 11 & +0.1 & -0.1 & 9.9 & +0.7 & +0.2 \\
\hline
\end{tabular}

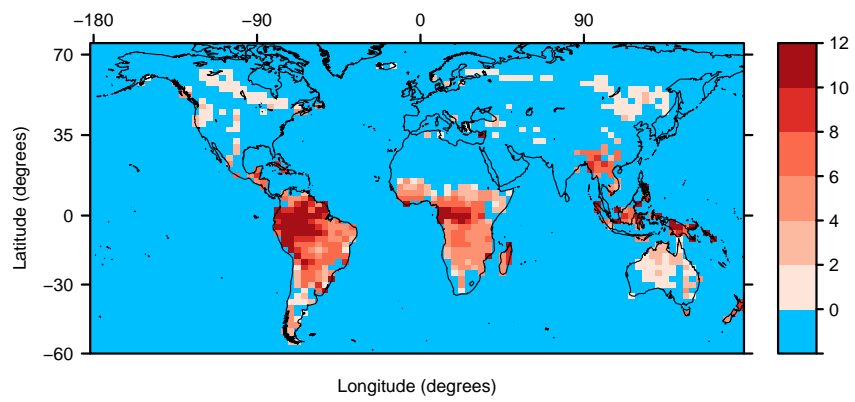

Figure 6. Grid cells included in the calculation of the mean $\mathrm{O}_{x}$ budget fluxes reported in Table 3 . Units range from 0 to 12 , indicating the number of months per year that each grid cell was included in the calculation. Using emissions from the BASE run, only those months when mean isoprene emissions were greater than $0.1 \mathrm{mg} \mathrm{C} \mathrm{m}^{-2} \mathrm{~h}^{-1}$ and mean $\mathrm{NO}_{x}$ emissions were less than $0.03 \mathrm{mg} \mathrm{N} \mathrm{m}^{-2} \mathrm{~h}^{-1}$ were included. Blue indicates that, based on this criterion, the grid cell was not included in the calculation at all.

tions of those grid cells included in this emissions regime, and also indicates how many months per year each grid cell was included.
From the budget terms in Table 3 for the BASE integrations, total mean $\mathrm{O}_{x}$ production varies across the schemes from $74 \mathrm{~mol} \mathrm{gc}^{-1} \mathrm{~s}^{-1}$ (here gc is grid cell) (CheT and CheT2) to $200 \mathrm{~mol} \mathrm{gc}^{-1} \mathrm{~s}^{-1}$ (LLSF). The majority of this variance is due to differences in the peroxy-radical + $\mathrm{NO}$ reactions $\left(\mathrm{HO}_{2}+\mathrm{NO}, \mathrm{MeO}_{2}+\mathrm{NO}\right.$ and other peroxy-radicals $\left.\left(\mathrm{RO}_{2}\right)+\mathrm{NO}\right)$. In CheT, CheT2 and AQUM, $\mathrm{RO}_{2}$ is primarily $\mathrm{ISO}_{2}, \mathrm{MACRO}_{2}$ (see Table 1 for definitions) and the peroxy acetyl radical $\left(\mathrm{MeCO}_{3}\right)$.

In all schemes, the oxidation of isoprene by $\mathrm{OH}$ is a source of peroxy radicals. In CheT, CheT2 and AQUM, the initial isoprene $+\mathrm{OH}$ reaction leads exclusively to the production of $\mathrm{ISO}_{2}$, whilst for $\mathrm{LLSF} \mathrm{MeO}_{2}$ is produced instead. Both $\mathrm{MeO}_{2}$ and $\mathrm{ISO}_{2}$ may react with $\mathrm{NO}$ producing $\mathrm{O}_{x}$ (propagation), or with other peroxy radicals producing peroxides

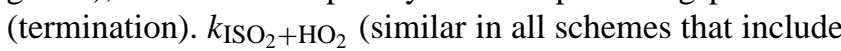
$\mathrm{ISO}_{2}$ ) is three times higher than $k_{\mathrm{MeO}_{2}+\mathrm{HO}_{2}}$ (identical in all

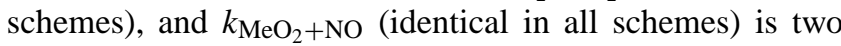
times higher than $k_{\mathrm{ISO}_{2}+\mathrm{NO}}$ (similar in all schemes that include $\mathrm{ISO}_{2}$ ). This suggests that the scheme that produces the largest fraction of $\mathrm{MeO}_{2}$ from isoprene oxidation (LLSF) should also show the highest total $\mathrm{RO}_{2}+\mathrm{NO}$ flux and consequently highest $\mathrm{O}_{3}$ levels, exactly as calculated (see Fig. 5d). 
Table 4. Whole tropospheric $\mathrm{O}_{x}$ budget $\left(\mathrm{Tg} \mathrm{yr}^{-1}\right)$ and $\mathrm{O}_{3}$ burden $(\mathrm{Tg})$ in the BASE run for different mechanisms, and changes due to climate change (CC), isoprene emissions with climate change (IC), anthropogenic emissions (AC), and land use (LC).

\begin{tabular}{llrrrrrr}
\hline Experiment & Mechanism & Prod & Loss & Net Chem & Influx & Dry Dep & Burden (Tg) \\
\hline BASE & CheT & 6188 & 5706 & 482 & -673 & 1155 & 379 \\
& CheT2 & 6234 & 5742 & 492 & -662 & 1154 & 380 \\
& AQUM & 6234 & 5776 & 458 & -733 & 1191 & 374 \\
& LLSF & 5979 & 5480 & 499 & -681 & 1180 & 360 \\
CC & & & & & & & \\
& CheT & 361 & 540 & -179 & -165 & -14 & 380 \\
& CheT2 & 349 & 530 & -181 & -165 & -16 & 380 \\
& AQUM & 350 & 515 & -165 & -149 & -17 & 374 \\
& LLSF & 329 & 500 & -171 & -150 & -21 & 360 \\
IC & & & & & & & \\
& CheT & 90 & 75 & 15 & 7 & 8 & 383 \\
& CheT2 & 113 & 94 & 20 & 9 & 11 & 385 \\
& AQUM & 128 & 97 & 31 & 17 & 14 & 380 \\
& LLSF & 154 & 122 & 32 & 11 & 21 & 367 \\
AC & & & & & & & \\
& CheT & -196 & -131 & -65 & -30 & -35 & 379 \\
& CheT2 & -160 & -112 & -47 & -12 & -36 & 380 \\
& AQUM & -188 & -109 & -80 & -44 & -36 & 376 \\
& LLSF & -160 & -109 & -51 & -23 & -28 & 364 \\
LC & & & & & & & \\
& CheT & -294 & -297 & 3 & 39 & -36 & 361 \\
& CheT2 & -314 & -317 & 3 & 41 & -38 & 361 \\
& AQUM & -351 & -350 & -1 & 49 & -50 & 357 \\
& LLSF & -346 & -305 & -41 & 22 & -63 & 346 \\
\hline
\end{tabular}

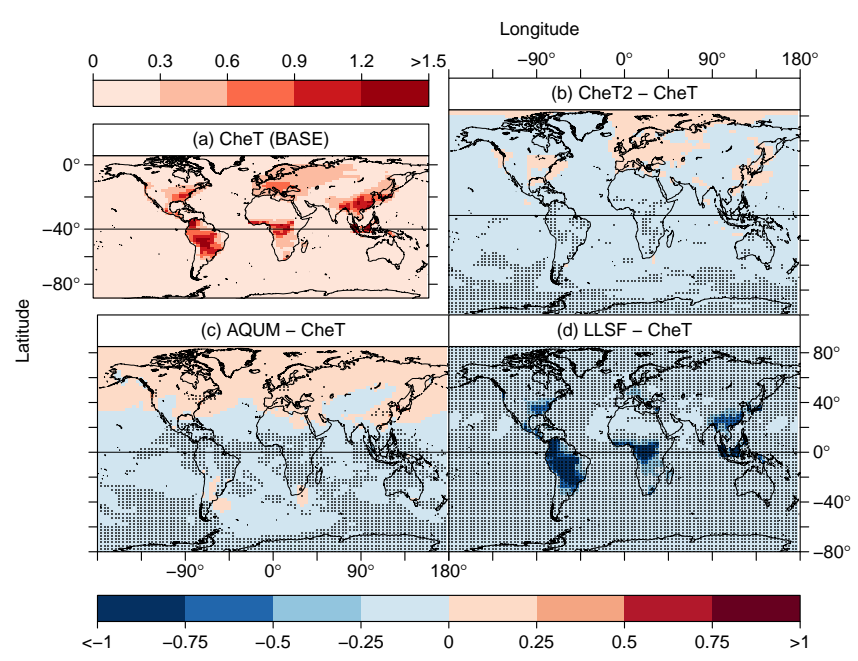

Figure 7. Difference in the present-day (2000, BASE) 5-year mean near-surface $(<720 \mathrm{~m}) \Sigma \mathrm{PAN}(\mathrm{ppb})$ between CheT isoprene chemistry and other isoprene chemical mechanisms. The stippling indicates where the difference is significant at the $5 \%$ level (greater than $\pm 2.5 \times$ the standard error).

In CheT, CheT2 and AQUM, once $\mathrm{ISO}_{2}$ is formed, it may be further oxidised to produce second-generation peroxy radicals such as $\mathrm{MACRO}_{2}$. In AQUM, reactions of $\mathrm{ISO}_{2}$ and
$\mathrm{MACRO}_{2}$ with NO lead to greater production of $\mathrm{O}_{3}$, as evident from the higher mean $\mathrm{RO}_{2}+\mathrm{NO}$ flux (Table 3): 51 (AQUM), 31 (CheT), $29 \mathrm{~mol} \mathrm{gc}^{-1} \mathrm{~s}^{-1}$ (CheT2). The reason for this is the inclusion in CheT and CheT2 of competing peroxy radical $+\mathrm{NO}$ reaction channels that do not lead to $\mathrm{O}_{3}$ formation. AQUM does not include the isoprene nitrate formation pathway from $\mathrm{ISO}_{2}$, which accounts for 4.4 and $10 \%$ of the total $\mathrm{ISO}_{2}+\mathrm{NO}$ flux in CheT and CheT2 respectively (Jenkin, 2012). Additionally, AQUM does not include MPAN formation from $\mathrm{MACRO}_{2}+\mathrm{NO}$, which contributes to a lower mean $\mathrm{MACRO}_{2}+\mathrm{NO} \rightarrow \mathrm{NO}_{2}$ flux in CheT and CheT2 compared to AQUM: 7.0 (CheT), 6.7 (CheT2) and $12 \mathrm{~mol} \mathrm{gc}^{-1} \mathrm{~s}^{-1}$ (AQUM).

Figure 7 shows total peroxyacyl nitrates $(\Sigma$ PAN $=$ PAN + MPAN + PPAN) near the surface in (a) CheT and (bd) the difference between CheT and the other schemes. Figure $7 \mathrm{~d}$ shows that, compared to CheT, there is much less $\Sigma$ PAN in LLSF (the $\Sigma$ PAN tropospheric burden in LLSF is $1.49 \mathrm{Tg}$ compared to $3.57 \mathrm{Tg}$ in $\mathrm{CheT}$ ). This follows since in LLSF, no $\Sigma$ PAN precursor radicals $\left(\mathrm{MeCO}_{3}\right.$ nor $\left.\mathrm{MACRO}_{2}\right)$ are produced from isoprene oxidation. As PANs are a source of $\mathrm{O}_{x}$ to remote regions, the low $\Sigma$ PAN in LLSF is likely the cause of the low $\mathrm{O}_{3}$ compared to CheT over the remote tropical oceans (a mean reduction of $10 \%$ between $\pm 20^{\circ}$ lat., Fig. 5d). Another consequence of reduced PAN formation is that more $\mathrm{NO}_{x}$ stays close to the isoprene source region. 


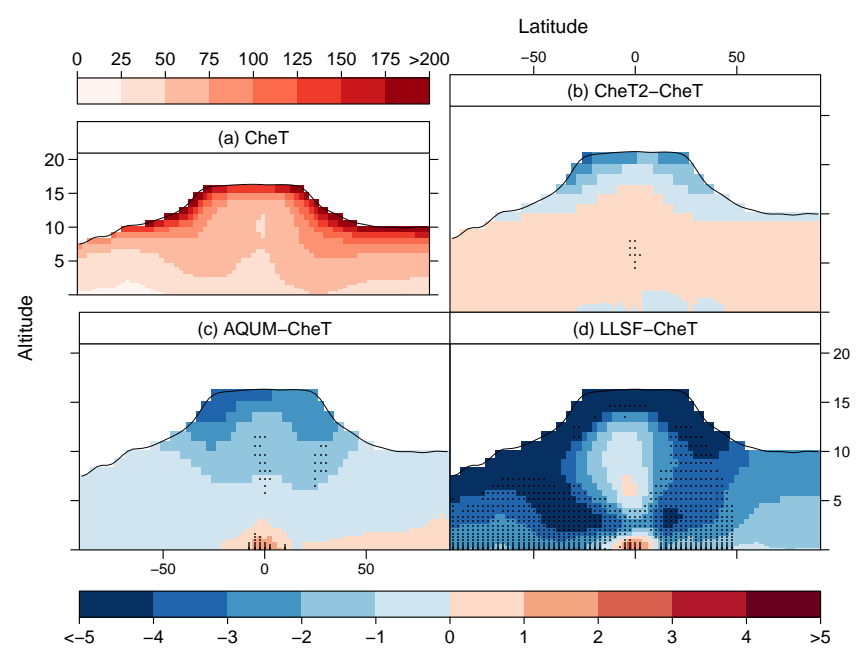

Figure 8. Difference in the present day (2000, BASE) five year mean zonal $\mathrm{O}_{3}(\mathrm{ppb})$ between CheT isoprene chemistry and other isoprene chemical mechanisms. The stippling indicates where the difference is significant at the $5 \%$ level (greater than $\pm 2.5 \times$ the standard error).

This contributes to the higher total $\mathrm{RO}_{2}+\mathrm{NO}$ flux, and hence higher $\mathrm{O}_{3}$, in these regions in LLSF.

Figure $7 \mathrm{~b}$ indicates that $\Sigma$ PAN in CheT2 is marginally lower than in CheT (the $\Sigma$ PAN tropospheric burden is about $6 \%$ lower). The cause of this is that the MPAN production rate in CheT2 is set to be $10 \%$ of that in CheT. The CheT2 rate is the value we would recommend, as it has been adjusted to take account of the fact that in UKCA, the species $\mathrm{MACRO}_{2}$ represents a set of peroxy radicals, not just the MPAN precursor methacrolyl peroxy radical (Jenkin, 2012).

Figure $7 \mathrm{c}$ shows that $\Sigma \mathrm{PAN}$ in AQUM is again marginally lower than in CheT (tropospheric $\Sigma$ PAN burden is $7 \%$ lower), this time due to the total absence of MPAN formation. However, the difference is small owing to the fact that in AQUM PAN production is faster, a result of higher production of the PAN precursor radical $\mathrm{MeCO}_{3}$ from isoprene oxidation. The mean mixing ratio of $\mathrm{MeCO}_{3}$ is $29 \%$ higher than the average of that in CheT and CheT2. Possible additional sources of $\mathrm{MeCO}_{3}$ in AQUM are the higher yield of methyglyoxal (MGLY), which rapidly reacts to form $\mathrm{MeCO}_{3}$ (CheT and CheT2 $=16 \mathrm{Tg}$ MGLY $\mathrm{yr}^{-1}$, AQUM $=40 \mathrm{Tg}$ MGLY $\mathrm{yr}^{-1}$ ). The higher yield of the $\mathrm{MeCO}_{3}$ peroxy radical also accounts for a fraction of the higher $\mathrm{RO}_{2}+\mathrm{NO}$ flux, and hence higher $\mathrm{O}_{3}$ in AQUM.

Extending the comparison to the wider troposphere, Table 4 gives the summed total $\mathrm{O}_{x}$ budget fluxes for the different schemes up to the tropopause. Fig. 8 shows the zonal mean ozone for the entire troposphere. The tropopause is shown by the black line. It is immediately apparent that the differences in $\mathrm{O}_{3}$ at the surface are not representative of the net effect on $\mathrm{O}_{3}$ over the entire troposphere. Whilst the $\mathrm{O}_{3}$ burdens of CheT and CheT2 are very similar (379 and

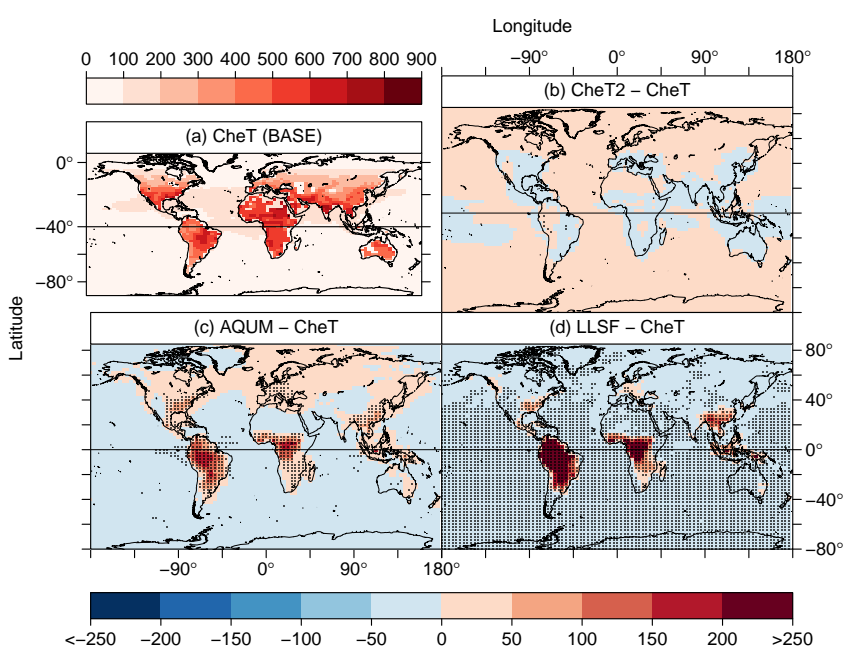

Figure 9. Difference in the present-day (2000, BASE) 5-year mean $\mathrm{O}_{3}$ dry deposition rate $\left(\mathrm{mol} \mathrm{gc}^{-1} \mathrm{~s}^{-1}\right)$ between CheT isoprene chemistry and other isoprene chemical mechanisms. The stippling indicates where the difference is significant at the $5 \%$ level (greater than $\pm 2.5 \times$ the standard error).

$380 \mathrm{Tg}$, respectively), AQUM has a lower burden $(374 \mathrm{Tg})$ and LLSF lower still $(360 \mathrm{Tg})$. This is consistent with the zonal difference plots (Fig. 8b-d), which show that away from the surface, both AQUM and LLSF give lower $\mathrm{O}_{3}$ than CheT, most notably in the tropical tropopause region.

Although the highest total tropospheric net chemical $\mathrm{O}_{3}$ production rate is calculated for LLSF, $\left(499 \mathrm{Tg} \mathrm{yr}^{-1}\right)$, overall the $\mathrm{O}_{3}$ burden is lower due to the higher rate of dry deposition $\left(1180 \mathrm{Tg} \mathrm{yr}^{-1}\right)$ compared to CheT $\left(1155 \mathrm{Tg} \mathrm{yr}^{-1}\right)$ and CheT2 (1154 $\mathrm{Tg} \mathrm{yr}^{-1}$ ) (see Fig. 9). The rate of dry deposition in AQUM is also high (1191 $\mathrm{Tg} \mathrm{yr}^{-1}$ ) (Fig. 9c). In UMUKCA dry deposition only occurs at the surface and is highest over forested regions. As AQUM and LLSF both produce higher $\mathrm{O}_{3}$ near the surface and notably over forested regions (high isoprene emitting regions), dry deposition is likely to be higher. This is indeed the case as illustrated by Fig. 9, which shows much higher $\mathrm{O}_{3}$ dry deposition fluxes over forested regions (e.g. Amazonia, central Africa) in AQUM and LLSF compared to CheT. CheT and CheT2 have higher rates of $\Sigma$ PAN formation, leading to more $\mathrm{O}_{3}$ production away from forested regions and the surface in general, thus resulting in lower $\mathrm{O}_{3}$ dry deposition and higher overall tropospheric $\mathrm{O}_{3}$ burdens.

Although tropospheric $\mathrm{O}_{3}$ varies little between CheT and CheT2 (Figs. 5 and 8), there are larger changes in other key oxidants, notably $\mathrm{OH}$. Due to the inclusion of additional $\mathrm{HO}_{x}$ regeneration pathways within the isoprene oxidation mechanism of CheT2 (namely the Peeters mechanism, Peeters et al., 2009), one would expect CheT2 to show higher levels of $\mathrm{OH}$ over high isoprene emitting regions. Figure 10 shows that $\mathrm{OH}$ in CheT2 is indeed higher than in CheT over the main isoprene emitting regions, with maximum increases 

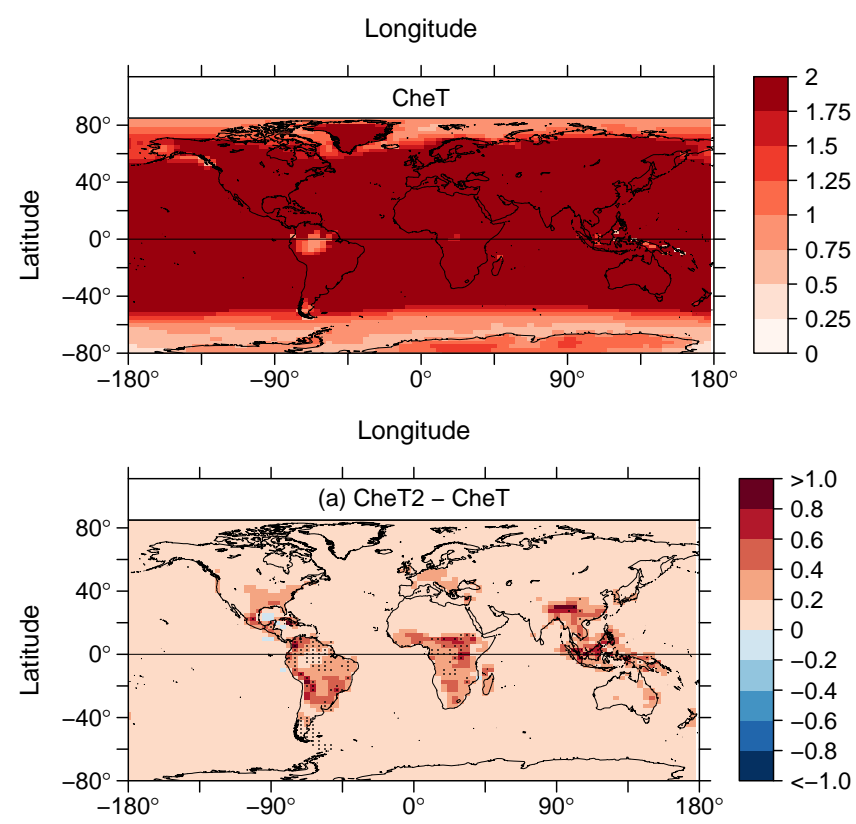

Figure 10. BASE 5-year mean near-surface (below $720 \mathrm{~m}$ ) $\mathrm{OH}$ $\left(10^{6}\right.$ molecule $\left.\mathrm{cm}^{-3}\right)$ in (a) CheT and (b) the difference between CheT and CheT2. The stippling indicates where the difference is significant at the $5 \%$ level (greater than $\pm 2.5 \times$ the standard error).

of approximately $50 \%$. Warwick et al. (2013) also calculated that including the Peeters mechanism in UM-UKCA gave higher $\mathrm{OH}$, improving agreement between modelled and measured values.

Levels of the main night-time oxidant, $\mathrm{NO}_{3}$, are higher in CheT2, AQUM and LLSF than in CheT (not shown). By percentage, the largest increases are calculated in the main isoprene emitting regions (Tropics). Here CheT2 shows increases in $\mathrm{NO}_{3}$ compared to CheT of around $30 \%$, whereas AQUM and LLSF show much greater increases in $\mathrm{NO}_{3}-$ up to 7 times more. This is a consequence of the lower formation rates of nitrate reservoirs in these schemes - thus $\mathrm{NO}_{3}$ formed from the base non-isoprene chemistry, by reactions such as $\mathrm{N}_{2} \mathrm{O}_{5}$ photolysis, is removed more slowly. These differences in $\mathrm{NO}_{3}$ levels have implications for the simulated rate of oxidation at night. As key oxidants, differences in both $\mathrm{OH}$ and $\mathrm{NO}_{3}$ are important for secondary organic aerosol (SOA) formation, which requires the formation of oxidised organic products.

Another mechanistic difference between CheT2 and CheT that has the potential to affect SOA production is the inclusion of epoxide formation in CheT2, based on the work of Paulot et al. (2009). In the tropics high levels of epoxides (50-70 ppt) reach an altitude of nearly $5 \mathrm{~km}$, and similar mixing ratios are present even in the lower Tropical Tropopause Layer (TTL) $(10-13 \mathrm{~km})$. Isoprene-derived epoxides are known to be precursors of organic aerosol formation (Paulot et al., 2009; Surratt et al., 2010), and as such, the presence of epoxides at high tropical altitudes could have

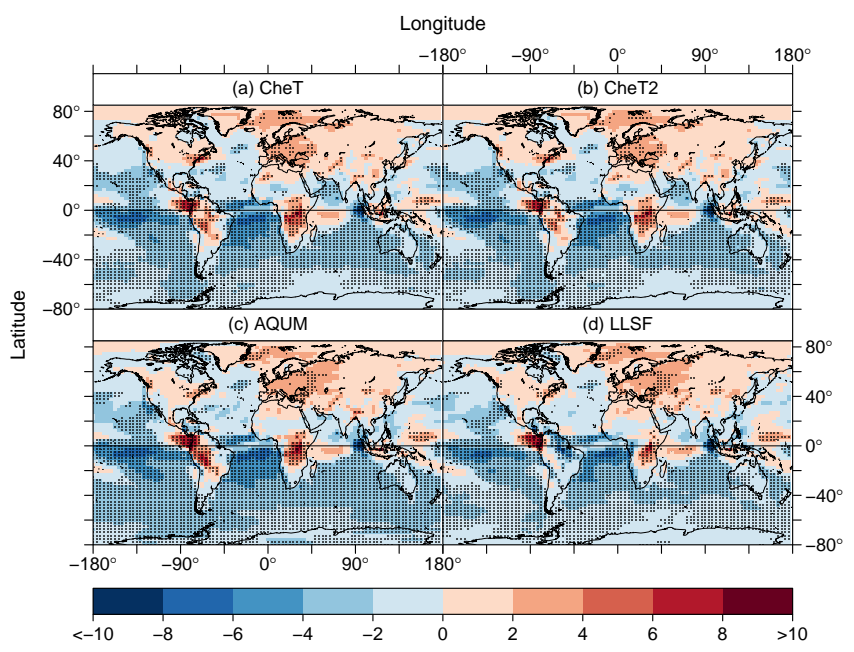

Figure 11. Changes in 5-year mean near-surface $(<720 \mathrm{~m}) \mathrm{O}_{3}$ (ppb) (2095-2000) caused by climate change (CC) for different isoprene chemical mechanisms. The stippling indicates where the difference is significant at the $5 \%$ level (greater than $\pm 2.5 \times$ the standard error).

important implications for cloud formation (e.g. Froyd et al., 2010).

\section{Future perturbation experiments}

In the previous section, we compared the different isoprene mechanisms under present-day conditions. In this section we examine how the mechanisms compare in the context of the future climate change (Sect. 5.1) and future isoprene emission change (Sect. 5.2) perturbation experiments described in Sect. 2.2.2.

\subsection{Climate change}

Figure 11a shows the change in near-surface $\mathrm{O}_{3}$ caused by our climate change scenario (CC) using the CheT scheme, as in Squire et al. (2014). Figure 11b-d shows the effect of CC using the CheT2, AQUM and LLSF isoprene schemes respectively. The general pattern of near-surface $\mathrm{O}_{3}$ changes is similar in all schemes. There are reductions over the oceans due to increased water vapour and subsequent loss of $\mathrm{O}_{3}$ via increased $\mathrm{O}^{1} \mathrm{D}+\mathrm{H}_{2} \mathrm{O}$. Over land where $\mathrm{O}_{3}$ production dominates (e.g. polluted Northern Hemispheric regions), near-surface $\mathrm{O}_{3}$ increases as the flux through $\mathrm{O}_{x}$ producing reactions usually increases with temperature. In regions with high isoprene emissions such as the Tropics, $\mathrm{O}_{3}$ also tends to increase, due to changes in PAN. PAN decomposition exhibits a strong temperature dependence, such that under the higher temperatures of climate change PAN decomposes faster, thus more $\mathrm{NO}_{x}$ will be present near the isoprene emission source. As a result, the mean $\Sigma \mathrm{RO}_{2}$ $\left(=\mathrm{HO}_{2}+\mathrm{MeO}_{2}+\mathrm{RO}_{2}\right)+\mathrm{NO}$ flux increases in these re- 


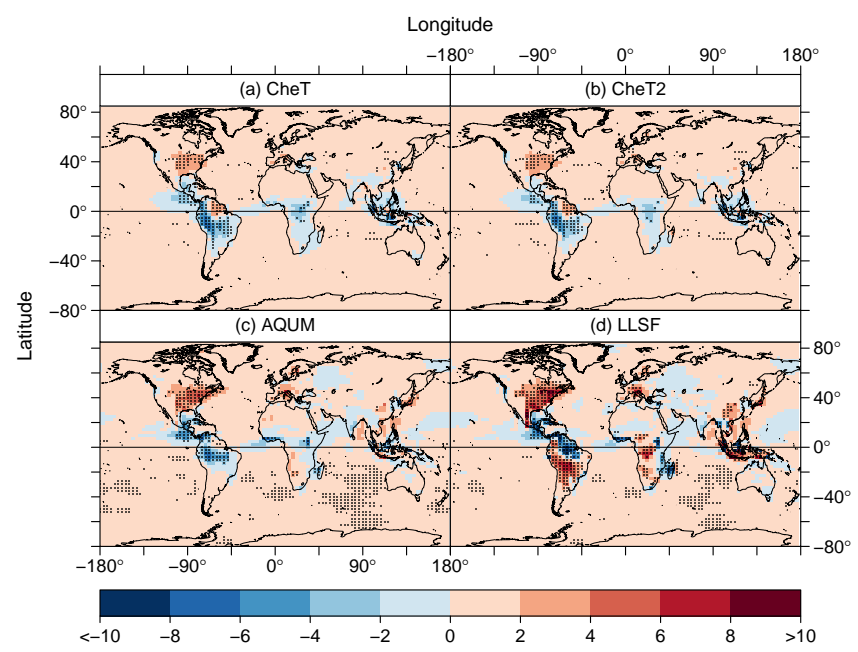

Figure 12. Changes in 5-year mean near-surface $(<720 \mathrm{~m}) \mathrm{O}_{3}$ (ppb) (2095-2000) caused by the change in isoprene emissions with climate (IC) for different isoprene chemical mechanisms. The stippling indicates where the difference is significant at the $5 \%$ level (greater than $\pm 2.5 \times$ the standard error).

gions (see CC entries in Table 3) $(\mathrm{AQUM}=+15$, CheT $=$ +10 , CheT2 $=+9.3 \mathrm{~mol} \mathrm{gc}^{-1} \mathrm{~s}^{-1}$ ), leading to higher $\mathrm{O}_{3}$ near the isoprene emission source.

Unlike with the other schemes, $\mathrm{O}_{3}$ decreases in highisoprene low- $\mathrm{NO}_{x}$ regions in simulations using LLSF. This is because LLSF produces very little PAN compared to the other schemes (see Sect. 4), so no increase in $\mathrm{NO}_{x}$ with temperature is calculated as would occur with increased PAN decomposition. The fact that $\mathrm{O}_{3}$ actually decreases is due

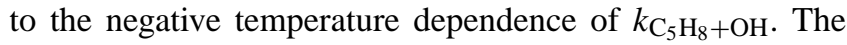
flux through this reaction under climate change decreases by $\sim 20 \%$ in all schemes, leading to associated increases in $\mathrm{OH}$ and isoprene export. Lower isoprene oxidation rates lead to a lower rate of peroxy radical production, and thus the $\mathrm{HO}_{2}+\mathrm{NO}$ and $\mathrm{MeO}_{2}+\mathrm{NO}$ reaction fluxes decrease in LLSF ( -1.8 and $-3.2 \mathrm{~mol} \mathrm{gc}^{-1} \mathrm{~s}^{-1}$, respectively, Table 3$)$. In schemes other than LLSF, this effect is masked by the large increase in $\mathrm{NO}_{x}$ from increased PAN decomposition. Despite large changes in tropospheric net chemical production due to climate change, the tropospheric $\mathrm{O}_{3}$ burdens in the $\mathrm{CC}$ experiment remain unaltered (Table 3 ).

We also explored how ozone changes with our future anthropogenic emission scenario (AC, not shown). This scenario is characterised by large reductions in $\mathrm{NO}_{x}$ emissions over the USA, Europe and Japan. The $\mathrm{O}_{3}$ response was remarkably similar for all the different isoprene mechanisms, presumably because the largest changes in anthropogenic emissions occur away from regions of high isoprene emissions. We conclude that the $\mathrm{O}_{3}-\mathrm{NO}_{x}$ response in these regions is controlled largely by the simple $\mathrm{NO}_{x}-\mathrm{HO}_{x}$ chemistry which is the same in all chemistry schemes. If, instead, the scenario had included large $\mathrm{NO}_{x}$ changes in the

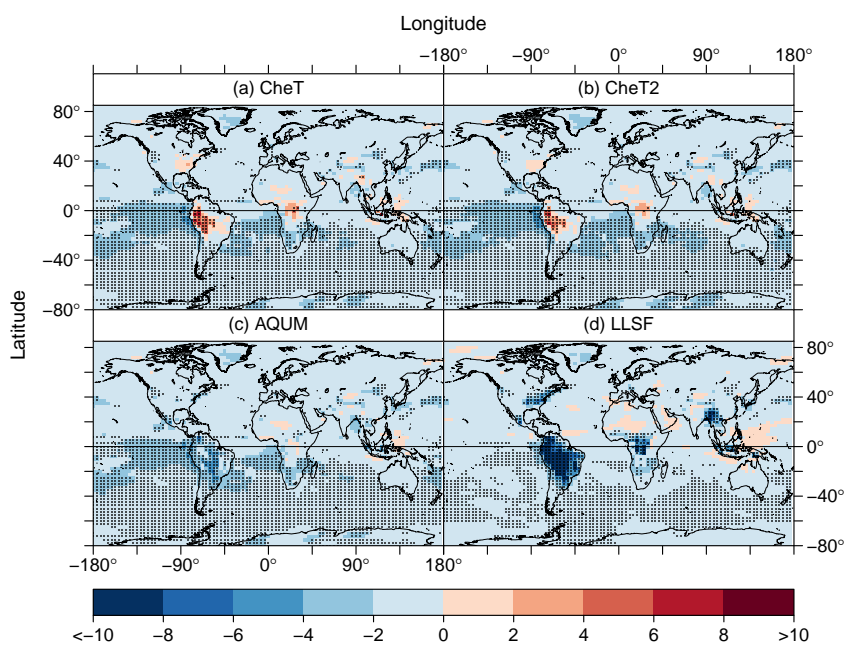

Figure 13. Changes in 5-year mean near-surface $(<720 \mathrm{~m}) \mathrm{O}_{3}$ (ppb) (2095-2000) caused by land use change (LC) for different isoprene chemical mechanisms. The stippling indicates where the difference is significant at the $5 \%$ level (greater than $\pm 2.5 \times$ the standard error).

Tropics where isoprene emissions are high, it is likely that the schemes would respond differently. It has previously been shown that changes in tropical $\mathrm{NO}_{x}$ associated with increased anthropogenic activity can lead to large changes in $\mathrm{O}_{3}$, e.g. Paulot et al. (2012) found that tropical $\mathrm{O}_{3}$ increased by $30 \%$ when $\mathrm{NO}_{x}$ emissions everywhere were set to those of the USA in terms of GDP per capita. Conducting a similar experiment with different isoprene chemical mechanisms would be a worthwhile extension to our work.

\subsection{Isoprene emission change}

In this section, we examine the results of the two isoprene emission change experiments: IC (the change in isoprene emissions with climate) and LC (the change in isoprene emissions with land use).

Figures 12 and 13 show the changes in surface $\mathrm{O}_{3}$ that occur for each of the different isoprene chemical mechanisms in the IC and LC experiments respectively. In both cases, the isoprene mechanism sensitivity is more pronounced than for the CC experiment (Sect. 5.1), which may be anticipated given that the perturbations in IC and LC specifically involve isoprene. On the scale of the whole troposphere, the $\mathrm{O}_{3}$ burden is enhanced in IC and reduced in LC for all schemes (Table 4). This is expected as in IC, ultimately, there is more $\mathrm{O}_{3}$ precursor and in LC there is less.

In the next three sections, we analyse the $\mathrm{O}_{3}$ trends in Figs. 12 and 13 using the corresponding $\mathrm{O}_{x}$ budget terms in Tables. 3 and 5. This is done for each distinct $\mathrm{O}_{x}$ production regime; Sect. 5.2.2 - $\mathrm{NO}_{x}$-limited regions where isoprene emissions increase, Sect. 5.2.3 $-\mathrm{NO}_{x}$-limited regions where isoprene emissions decrease, and Sect. 5.2.4 - VOC-limited 
regions where isoprene emissions increase. In the next section (Sect. 5.2.1), we discuss how each of these regimes is defined.

\subsubsection{Defining distinct $\mathrm{O}_{x}$ production regimes}

In the IC experiment, a mean global increase in isoprene emissions $\left(+78 \mathrm{Tg} \mathrm{Cyr}^{-1}\right)$ is calculated. Within the high isoprene emitting regions, there are three distinct regimes of change, which we will denote as IC regions 1, 2 and 3 (ICr1, $\mathrm{ICr} 2$ and ICr3). Each regime is defined on a per-month-pergrid-cell basis as follows:

1. $\mathrm{ICr} 1$ is months when isoprene emissions in a grid-cell increase by more than $0.05 \mathrm{Tg}$ and the environment is $\mathrm{NO}_{x}$-limited.

2. $\mathrm{ICr} 2$ is months when isoprene emissions in a grid-cell decrease by more than $0.05 \mathrm{Tg}$ and the environment is $\mathrm{NO}_{x}$-limited.

3. ICr3 is months when isoprene emissions in a grid-cell increase by more than $0.005 \mathrm{Tg}$ and the environment is VOC-limited.

The isoprene emission change criteria is an order of magnitude smaller for ICr3 than for ICr1 or ICr2, owing to the greater sensitivity of increasing isoprene emissions in a VOC-limited environment compared to a $\mathrm{NO}_{x}$-limited environment. Here we define VOC-limited as where the ratio of $L_{\mathrm{N}}$ (loss of radicals from reactions with $\mathrm{NO}$ and $\mathrm{NO}_{2}$ ) to $Q$ (the sum of all radical sinks) is more than 0.5 (Kleinman et al., 1997; Wiedinmyer et al., 2006). $\mathrm{NO}_{x}$-limited is defined as where $L_{N} / Q$ is less than 0.5 (Kleinman et al., 1997; Wiedinmyer et al., 2006). To ensure that each regime includes the same grid cells in CheT, CheT2, AQUM and LLSF, $L_{N} / \mathrm{Q}$ values from $C h e T$ were used in all cases. The geographical location of those grid cells included in each regime are shown Fig. 14, indicating also how many months per year each grid cell was included. Table 5 gives mean $\mathrm{O}_{x}$ budget fluxes for these three regimes, which will be discussed in Sects. 5.2.25.2.4.

In LC, the pattern of change in all high isoprene emitting regions is the same as that of $\mathrm{ICr} 2$ : reductions in isoprene emissions $\left(-190 \mathrm{Tg} \mathrm{Cyr}^{-1}\right.$ globally) in a $\mathrm{NO}_{x}$-limited environment. As such, LC and ICr2 will be discussed together. Note that those high isoprene-emitting regions that were VOC-limited in IC (ICr3, e.g. southeastern USA) are $\mathrm{NO}_{x}$ limited in LC owing to the inclusion of an anthropogenic emission scenario of large Northern Hemispheric $\mathrm{NO}_{x}$ emission reductions. The mean $\mathrm{O}_{x}$ budget terms for $\mathrm{LC}$ are given in Table 3. These were calculated using the same grid cells as the other budgets in this table (see Fig. 6).

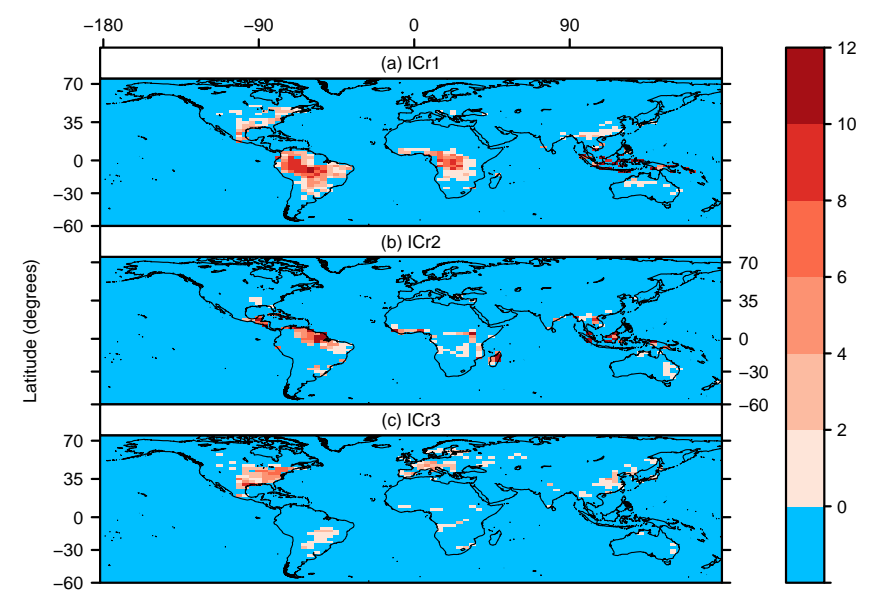

Figure 14. Grid cells included in the calculation of the mean $\mathrm{O}_{x}$ budget fluxes reported in Table 5. Units range from 0 to 12 , indicating the number of months per year that each grid cell was included in the calculation. For each region (ICr1, ICr2 and ICr3) different criteria were used to select which months a grid cell should be included, as follows: (a) ICr1 is months when isoprene emissions increase by more than $0.05 \mathrm{Tg}$ and the environment is $\mathrm{NO}_{x}$ limited. (b) $\mathrm{ICr} 2$ is months when isoprene emissions decrease by more than $0.05 \mathrm{Tg}$ and the environment is $\mathrm{NO}_{x}$-limited. (c) $\mathrm{ICr} 3$ is months when isoprene emissions increase by more than $0.005 \mathrm{Tg}$ and the environment is VOC-limited. See text for how $\mathrm{NO}_{x}$-limited and VOC-limited are defined. Blue indicates that, according to the above criteria, the grid cell was not included in the calculation at all.

\subsection{2 $\mathrm{NO}_{x}$-limited regions where isoprene emissions increase (ICr1)}

In ICr1 (where isoprene emissions increase in a $\mathrm{NO}_{x}$-limited environment), both total chemical $\mathrm{O}_{x}$ production and total chemical $\mathrm{O}_{x}$ loss increase in all schemes, owing to greater $\mathrm{O}_{3}$ precursor emissions. Changes in $\mathrm{O}_{x}$ loss are similar in all schemes, being driven largely by an increase in isoprene ozonolysis (in the range +21 to $+27 \mathrm{~mol} \mathrm{gc}^{-1} \mathrm{~s}^{-1}$ across the schemes). On the other hand, total $\mathrm{O}_{x}$ production varies considerably between schemes, from $\sim+1 \mathrm{~mol} \mathrm{gc}^{-1} \mathrm{~s}^{-1}$ in CheT and CheT2, to $+90 \mathrm{~mol} \mathrm{gc}^{-1} \mathrm{~s}^{-1}$ in LLSF. The overall result is a decrease in net $\mathrm{O}_{x}$ production for CheT and CheT2 (each $-16 \mathrm{~mol} \mathrm{gc}^{-1} \mathrm{~s}^{-1}$ ), close to no net change in AQUM, and a net increase in LLSF $\left(+50 \mathrm{~mol} \mathrm{gc}^{-1} \mathrm{~s}^{-1}\right)$. As explained in Sect. 4 , the primary peroxy radical produced from isoprene oxidation in LLSF is $\mathrm{MeO}_{2}$, whilst in the other schemes it is $\mathrm{ISO}_{2}$ and $\mathrm{MACRO}_{2} . \mathrm{MeO}_{2}$ has a higher propensity for reaction with $\mathrm{NO}$ than $\mathrm{ISO}_{2}$ or $\mathrm{MACRO}_{2}$, thus an increase in isoprene emissions (as in ICr1) will increase the total $\mathrm{RO}_{2}+\mathrm{NO}$ flux by a greater amount in LLSF than in the other schemes. Note that the MPAN and isoprene nitrate formation pathways that compete directly with $\mathrm{O}_{x}$ production from isoprene-derived peroxy radicals in CheT and CheT2 are not included in AQUM. Accordingly, increasing 
Table 5. Changes in the near-surface (below $720 \mathrm{~m}$ ) mean $\mathrm{O}_{x}$ budget fluxes from the IC experiment (mol gc ${ }^{-1} \mathrm{~s}^{-1}$ ). The budget is split into three regimes; $\mathrm{ICr} 1-\mathrm{NO}_{x}$-limited regions with large increases in isoprene emissions, $\mathrm{ICr} 2-\mathrm{NO}_{x}$-limited regions with large decreases in isoprene emissions, and ICr3 - VOC-limited regions with large increases in isoprene emissions. See Fig. 14 for which grid cells were included in each regime, and see text for precise definitions of the regimes.

\begin{tabular}{|c|c|c|c|c|c|c|c|c|c|c|c|c|}
\hline \multirow[t]{2}{*}{ Flux } & \multicolumn{3}{|c|}{ CheT } & \multicolumn{3}{|c|}{ CheT2 } & \multicolumn{3}{|c|}{ AQUM } & \multicolumn{3}{|c|}{ LLSF } \\
\hline & ICr1 & $\mathrm{ICr} 2$ & $\mathrm{ICr} 3$ & ICr1 & $\mathrm{ICr} 2$ & $\mathrm{ICr} 3$ & ICr1 & $\mathrm{ICr} 2$ & $\mathrm{ICr} 3$ & ICr1 & $\mathrm{ICr} 2$ & $\mathrm{ICr} 3$ \\
\hline $\mathrm{HO}_{2}+\mathrm{NO}$ & -6 & +14 & +14 & -6 & +14 & +15 & +2 & -17 & +27 & +33 & -60 & +29 \\
\hline $\mathrm{MeO}_{2}+\mathrm{NO}$ & -3 & +9 & +1 & -3 & +9 & +1 & -1 & -3 & +5 & +58 & -93 & +27 \\
\hline $\mathrm{RO}_{2}+\mathrm{NO}$ & +11 & -35 & +15 & +10 & -33 & +15 & +23 & -59 & +23 & -1.4 & +3.7 & -0.9 \\
\hline $\mathrm{OH}+\mathrm{RCOOH}$ & 0 & 0 & -0.2 & 0 & 0 & -0.1 & 0 & 0 & -0.1 & 0 & 0 & -0.1 \\
\hline $\mathrm{RONO}_{2}+\mathrm{OH}$ & -0.1 & -0.4 & +0.5 & -0.1 & -0.2 & +0.2 & -0.0 & +0.0 & -0.0 & -0.0 & +0.0 & -0.0 \\
\hline $\mathrm{RONO}_{2}+\mathrm{h} v$ & +0.0 & -0.0 & +0.0 & +0.0 & -0.4 & +0.1 & -0.0 & -0.0 & +0.0 & +0.0 & -0.0 & +0.0 \\
\hline $\mathrm{O}^{1} \mathrm{D}+\mathrm{H}_{2} \mathrm{O}$ & -3 & 0 & +0.9 & -3 & +1 & +0.9 & -1 & -4 & +1.7 & +6 & -12 & +2.0 \\
\hline Minor loss rxns & 0 & 0 & 0 & 0 & 0 & 0 & 0 & 0 & 0 & 0 & 0 & 0 \\
\hline $\mathrm{HO}_{2}+\mathrm{O}_{3}$ & 0 & 0 & +1.3 & 0 & -1 & +2.1 & 0 & -6 & +4.0 & +7 & -10 & +2.6 \\
\hline $\mathrm{OH}+\mathrm{O}_{3}$ & -2 & +5 & -0.8 & -2 & +5 & -0.7 & -2 & +4 & -0.1 & -2 & +3 & -0.2 \\
\hline $\mathrm{O}_{3}+$ alkene & +22 & -16 & +1.9 & +21 & -14 & +1.6 & +24 & -15 & +1.9 & +27 & -13 & +1.7 \\
\hline $\mathrm{N}_{2} \mathrm{O}_{5}+\mathrm{H}_{2} \mathrm{O}$ & 0 & 0 & -0.3 & 0 & 0 & -0.3 & 0 & 0 & -0.3 & 0 & 0 & +0.0 \\
\hline $\mathrm{NO}_{3}$ Loss & 0 & -3 & +3.2 & 0 & -3 & +2.9 & +2 & -5 & +2.9 & +2 & -4 & +1.9 \\
\hline $\mathrm{NO}_{\mathrm{y}}$ Wet Dep & 0 & 0 & -0.5 & 0 & 0 & -0.4 & 0 & 0 & -0.3 & 0 & 0 & -0.0 \\
\hline$\Sigma \mathrm{RO}_{2}+\mathrm{NO}$ & +2 & -12 & +30 & +1 & -10 & +31 & +24 & -79 & +55 & +90 & -149 & +55 \\
\hline Tot. Chem Prod & +1.9 & -12 & +31 & +0.7 & -9.8 & +32 & +24 & -79 & +56 & +90 & -149 & +54 \\
\hline Tot. Chem Loss & +17 & -13 & +5.7 & +16 & -11 & +6.2 & +23 & -26 & +9.8 & +40 & -36 & +7.9 \\
\hline Net Chem & -16 & -0.4 & +25 & -16 & +1.4 & +26 & +1.1 & -53 & +46 & +50 & -113 & +47 \\
\hline $\mathrm{O}_{3}$ Dry Dep & -25 & 0 & +35 & -23 & +3 & +34 & -12 & -33 & +58 & +51 & -81 & +66 \\
\hline $\mathrm{NO}_{\mathrm{y}}$ Dry Dep & -1 & +6 & -1.4 & -1 & +6 & -0.8 & -1 & +3 & +2.4 & -1 & +2 & +0.4 \\
\hline
\end{tabular}

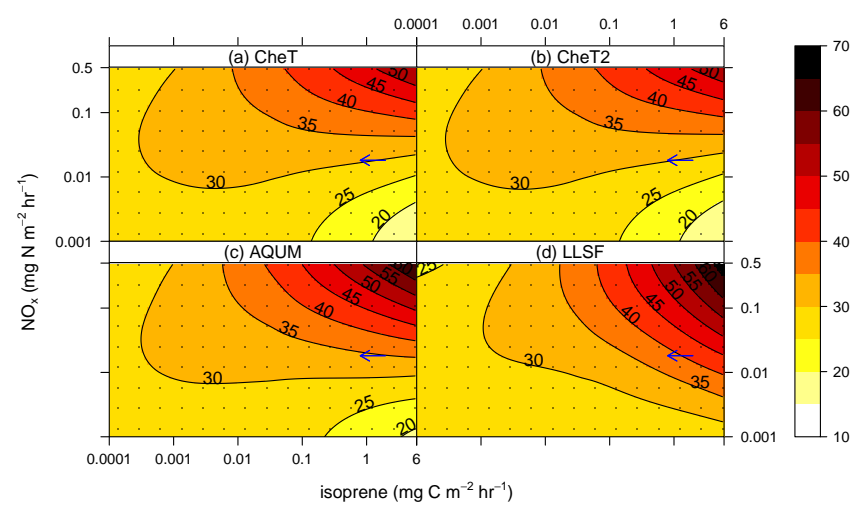

Figure 15. Monthly mean surface $\mathrm{O}_{3}(\mathrm{ppb})$ as a function of monthly mean $\mathrm{NO}_{x}$ and isoprene emissions from UM-UKCA. Data from all of the UM-UKCA experiments in this study are used to generate this plot. The $\mathrm{NO}_{x}$ and isoprene emission rates used are identical to those used in Figs. 1 and 3.

isoprene emissions in AQUM leads to a larger increase in the $\Sigma \mathrm{RO}_{2}+\mathrm{NO}$ flux than in CheT or CheT2.

\subsection{3 $\mathrm{NO}_{x}$-limited regions where isoprene emissions decrease (LC and ICr2)}

In $\mathrm{LC}$ and $\mathrm{ICr} 2$ (where isoprene emissions are reduced in a $\mathrm{NO}_{x}$-limited environment), the opposite trend is calculated compared to ICr1. Both $\mathrm{O}_{x}$ loss and production decrease due to lower levels of $\mathrm{O}_{3}$ precursor emissions. As with $\mathrm{ICr} 1$, the change in $\mathrm{O}_{x}$ loss is similar in all schemes, being driven by reductions in isoprene ozonolysis (on average -11 (LC) and $-15 \mathrm{~mol} \mathrm{gc}^{-1} \mathrm{~s}^{-1}$ (ICr2) $\left.(\sim-50 \%)\right)$. On the other hand, total $\mathrm{O}_{x}$ production varies considerably between schemes (from -1.7 (LC) and $\sim-10 \mathrm{~mol} \mathrm{gc}^{-1} \mathrm{~s}^{-1}$ (ICr2) in CheT and CheT2, to -45 (LC) and $-149 \mathrm{~mol} \mathrm{gc}^{-1} \mathrm{~s}^{-1}$ (ICr2) in LLSF). The reduction in isoprene emissions causes a proportionally larger decrease in $\Sigma \mathrm{RO}_{2}+\mathrm{NO}$ for LLSF compared to the other schemes due to the preferential formation of $\mathrm{MeO}_{2}$ from isoprene oxidation compared to other peroxy radicals. This leads to a large reduction in net $\mathrm{O}_{x}$ formation in LLSF (-24 (LC), $-113 \mathrm{~mol} \mathrm{gc}^{-1} \mathrm{~s}^{-1}$ (ICr2)). For AQUM, the lower rate of formation of $\mathrm{NO}_{x}$ reservoir species compared to CheT or CheT2 leads to a greater reduction in $\Sigma \mathrm{RO}_{2}+\mathrm{NO}$, overall leading to a moderate reduction in net $\mathrm{O}_{x}$ production ( $-4.0(\mathrm{LC}),-53 \mathrm{~mol} \mathrm{gc}^{-1} \mathrm{~s}^{-1}$ (ICr2)). Finally, for CheT and CheT2, the increase in $\mathrm{O}_{3}$ 
caused by the reduction in isoprene ozonolysis outweighs reductions in $\mathrm{O}_{3}$ caused by reductions in $\Sigma \mathrm{RO}_{2}+\mathrm{NO}$, leading overall to increases in net $\mathrm{O}_{x}$ production (each +6.7 (LC), $+1.4 \mathrm{~mol} \mathrm{gc}^{-1} \mathrm{~s}^{-1}$ (ICr2, CheT2)) or close to no change $\left(-0.4 \mathrm{~mol} \mathrm{gc}^{-1} \mathrm{~s}^{-1}(\mathrm{ICr} 2, \mathrm{CheT})\right)$.

\subsubsection{VOC-limited regions where isoprene emissions increase ( $\mathrm{ICr} 3)$}

For $\mathrm{ICr} 3$, where isoprene emissions increase in a VOClimited environment, all schemes show the same trend of increased near-surface $\mathrm{O}_{3}$. In such an environment, the effect of adding isoprene favours $\mathrm{O}_{3}$ production to a far greater extent than $\mathrm{O}_{3}$ loss, owing to the availability of $\mathrm{NO}_{x}$. The result is that in all schemes, even CheT and CheT2 that have a lower overall propensity for $\mathrm{O}_{x}$ production, net $\mathrm{O}_{x}$ production increases $(+25$ (CheT), +26 (CheT2), +46 (AQUM), $+47 \mathrm{~mol} \mathrm{gc}^{-1} \mathrm{~s}^{-1}$ (LLSF), Table 5).

\section{A comparison of $\mathrm{O}_{3}$ sensitivity to precursor emissions in global and box models}

Figure 15 shows $\mathrm{O}_{3}$ isopleths as a function of $\mathrm{NO}_{x}$ and isoprene emission, similar to that in Fig. 1, but for the reduced schemes and, in this case, using $\mathrm{O}_{3}$ mixing ratio data from the global UM-UKCA simulations. Data from all of the experiments discussed in Sect. 5 were included in Fig. 15 to maximise the $\mathrm{NO}_{x}-$ isoprene emission space that was covered (the exact same emission values were earlier used to produce Figs. 1 and 3). The arrows in Fig. 15 indicate the mean emission of $\mathrm{NO}_{x}$ and isoprene in the Amazon region, before and after land use change (i.e. those emissions used in the AC and LC integrations). For CheT and CheT2, the gradient of the contours is such that $\mathrm{O}_{3}$ increases with the isoprene emission change, but for the other two schemes, $\mathrm{O}_{3}$ decreases. This is consistent with the picture presented in Fig. 13.

Comparing Fig. 15 to Figs. 1 and 3, the principal features of the isopleths derived from the global model are captured well by the box model simulations. This includes resolution of the differences between the schemes, such as the higher $\mathrm{O}_{3}$ in LLSF and AQUM at high isoprene emissions compared to CheT and CheT2. In fact, compared to the global model, the box model simulations tend to accentuate the chemical differences between the schemes. With the isopleths derived from the global model simulations, the effects of advection and deposition somewhat buffer the chemical differences, leading to a narrower range of $\mathrm{O}_{3}$ mixing ratios and more similar isopleths. Consequently, the $\mathrm{O}_{3}$ levels reached in the global simulations (less than $70 \mathrm{ppb}$ ) are generally lower than in the box model (approaching $170 \mathrm{ppb}$ ). The qualitative agreement between the isopleths derived from the box model and global model suggests that the method of constructing such isopleths with the far less computationally expensive box models is a convenient way to quickly and accurately assess differences between chemical mechanisms. The fact that Figs. 1, 3 and 15 show good agreement, gives us confidence that use of the box model to compare to a near-explicit mechanism (the MCM) with reduced schemes is relevant for global model experiments.

\section{Conclusions}

Here we have examined the effect on tropospheric $\mathrm{O}_{3}$ of using different reduced isoprene chemical mechanisms currently used in ESMs, to simulate the impact of climate change (CC), isoprene emission changes with climate (IC), anthropogenic emission changes (AC), and land use change (LC). Between the CheT and CheT2 schemes, there is no significant difference in near-surface $\mathrm{O}_{3}$, though $\mathrm{OH}$ is higher in isoprene-emitting regions in CheT2 due to the inclusion of additional $\mathrm{HO}_{x}$ regeneration pathways from isoprene oxidation. For the BASE run, in the major isoprene emitting regions AQUM and LLSF give $\mathrm{O}_{3}$ levels that are at least $10 \mathrm{ppb}$ higher than with the other schemes. This is due to differences in the speciation of peroxy radicals produced by the schemes. LLSF produces a large yield of $\mathrm{MeO}_{2}$ that rapidly reacts with $\mathrm{NO}$ to form $\mathrm{O}_{3}$. The other schemes produce $\mathrm{ISO}_{2}$, which has a higher rate of radical termination than $\mathrm{MeO}_{2}$, thus leading to less $\mathrm{O}_{3}$ formation. AQUM produces more $\mathrm{O}_{3}$ than CheT and CheT2 because the scheme makes less ISON and no MPAN - both important $\mathrm{NO}_{x}$ sinks near the isoprene emission source.

Turning to the future perturbation experiments, in $\mathrm{CC}$, the $\mathrm{O}_{3}$ climate change sensitivity is similar in all schemes, though LLSF responds differently over the Amazon, due to the fact that no PANs are produced. In the anthropogenic emission change experiment (AC) (characterised by large $\mathrm{NO}_{x}$ emission reductions in the Northern Hemisphere), all mechanisms respond in a similar way. This suggests that the $\mathrm{O}_{3}-\mathrm{NO}_{x}$ response is driven largely by the simple $\mathrm{NO}_{x}-\mathrm{HO}_{x}$-alkane chemistry, which is the same for all schemes.

With the isoprene emission change experiments (IC and $\mathrm{LC})$, there are changes in both isoprene ozonolysis $\left(\mathrm{O}_{x}\right.$ loss $)$ and the $\Sigma \mathrm{RO}_{2}+\mathrm{NO}$ flux ( $\mathrm{O}_{x}$ production). For the land use change experiment (LC), isoprene emissions decrease leading to a reduction in both processes. The ozonolysis changes are the same in all schemes, but the $\mathrm{RO}_{2}+\mathrm{NO}$ reductions differ widely between schemes. For LLSF, reductions are largest owing to the high yield of $\mathrm{MeO}_{2}$, which favours reaction with $\mathrm{NO}$ compared to higher isoprene-derived peroxy radicals $\left(\mathrm{ISO}_{2}\right.$ and $\left.\mathrm{MACRO}_{2}\right)$. These are produced by the other schemes, leading overall to a smaller reduction in $\mathrm{RO}_{2}+\mathrm{NO}$. In LLSF and AQUM the reduction in $\mathrm{RO}_{2}+\mathrm{NO}$ is sufficient to cause a net decrease in near surface $\mathrm{O}_{3}$ in response to land use. This is not the case for CheT and CheT2, however, due to the formation of MPAN and ad- 
ditional ISON. For IC (increase in emissions), the opposite trends are calculated, though AQUM is in closer agreement with CheT and CheT2. This is most likely due to smaller net isoprene emission changes in IC compared to LC. In IC (where isoprene emissions increase under VOC-limited conditions (e.g. southeast USA)), all schemes show a net increase in near surface $\mathrm{O}_{3}$ owing to an increase in isoprene emissions that favours $\mathrm{O}_{x}$ production under such conditions.

Using the CheT scheme, Squire et al. (2014) found that the calculated increases in $\mathrm{O}_{3}$ due to cropland expansion (LC) were too small to cause a significant increase in $\mathrm{O}_{3}$ induced vegetation damage. As the three additional mechanisms examined here simulate similar or negative changes in $\mathrm{O}_{3}$ with cropland expansion, this conclusion would not change with the use of these schemes, and further calculations (not shown) demonstrate this to be the case.

Using the emissions and $\mathrm{O}_{3}$ data from all of the global model experiments, we were able to construct $\mathrm{O}_{3}$ isopleths in terms of $\mathrm{NO}_{x}$ and isoprene emissions. These isopleths explain the global model response to isoprene emission changes. Using these same $\mathrm{O}_{3}$ precursor emissions, we constructed $\mathrm{O}_{3}$ isopleths using a box model. We find there is good qualitative agreement between those isopleths derived from the global model and those from the box model. This suggests that comparing chemical mechanisms within a box model is a computationally efficient and useful tool for assessing mechanistic performance in complex global models. Furthermore, the agreement between box and global models gives us confidence that the comparison between a box model and a near-explicit mechanism is relevant to the global model experiments. The findings reported here should help to guide mechanistic development strategies. For example, we find that the LLSF scheme produces much higher $\mathrm{O}_{3}$ near isoprene source regions than the other three schemes. This was the only scheme where only simple peroxy radicals were produced, and, crucially there was no PAN production from isoprene chemistry. Adding simple parameterisation of PAN formation would improve the distribution of $\mathrm{O}_{3}$. Here, we have shown that the magnitude and even the sign of the $\mathrm{O}_{3}$ response is affected by the choice of reduced isoprene mechanism.

Acknowledgements. We would like to acknowledge funding from the National Environmental Research Council (NERC), the National Centre for Atmospheric Science (NCAS) and the European Research Council (ERC) under project no 267760 ACCI. A. T. Archibald would like to acknowledge funding from the Herschel Smith Fund. Our thanks also to Paul Young for pointing out, and helping us correct, errors in our calculation of statistical significance. Finally, we would like to thank the editor and reviewers for their constructive critiques, which have helped improve this work.

Edited by: P. O. Wennberg

\section{References}

Archibald, A. T., Cooke, M. C., Utembe, S. R., Shallcross, D. E., Derwent, R. G., and Jenkin, M. E.: Impacts of mechanistic changes on $\mathrm{HO}_{x}$ formation and recycling in the oxidation of isoprene, Atmos. Chem. Phys., 10, 8097-8118, doi:10.5194/acp-108097-2010, 2010a.

Archibald, A. T., Jenkin, M. E., and Shallcross, D. E.: An isoprene mechanism intercomparison, Atmos. Environ., 44, 5356-5364, doi:10.1016/j.atmosenv.2009.09.016, 2010b.

Archibald, A. T., Levine, J. G., Abraham, N. L., Cooke, M. C., Edwards, P. M., Heard, D. E., Jenkin, M. E., Karunaharan, A., Pike, R. C., Monks, P. S., Shallcross, D. E., Telford, P. J., Whalley, L. K., and Pyle, J. A.: Impacts of $\mathrm{HO}_{x}$ regeneration and recycling in the oxidation of isoprene: consequences for the composition of past, present and future atmospheres, Geophys. Res. Lett., 38, L05804, doi:10.1029/2010GL046520, 2011.

Aumont, B., Szopa, S., and Madronich, S.: Modelling the evolution of organic carbon during its gas-phase tropospheric oxidation: development of an explicit model based on a self generating approach, Atmos. Chem. Phys., 5, 2497-2517, doi:10.5194/acp-52497-2005, 2005.

Browne, E. C. and Cohen, R. C.: Effects of biogenic nitrate chemistry on the $\mathrm{NO}_{x}$ lifetime in remote continental regions, Atmos. Chem. Phys., 12, 11917-11932, doi:10.5194/acp-1211917-2012, 2012.

Cameron-Smith, P., Prather, M. J., Lamarque, J., Hess, P. G., Connell, P. S., Bergmann, D. J., and Vitt, F. M.: The super-fast chemistry mechanism for IPCC AR5 simulations with CCSM, in: American Geophysical Union, Fall Meeting, 18 December 2009, San Francisco, A54A-08, 2009.

Chameides, W., Lindsay, R., Richardson, J., and Kiang, C.: The role of biogenic hydrocarbons in urban photochemical smog - Atlanta as a case-study, Science, 241, 1473-1475, 1988.

Dodge, M.: Combined use of modeling techniques and smog chamber data to derive ozone-precursor relationships, in: Proceedings of the International Conference on Photochemical Oxidant Pollution and its Control, US Environmental Protection Agency, Research Triangle Park, NC, USA, 881-889, 1977.

Farmer, D. K. and Cohen, R. C.: Observations of $\mathrm{HNO}_{3}, \Sigma \mathrm{AN}$, $\Sigma \mathrm{PN}$ and $\mathrm{NO}_{2}$ fluxes: evidence for rapid $\mathrm{HO}_{x}$ chemistry within a pine forest canopy, Atmos. Chem. Phys., 8, 3899-3917, doi:10.5194/acp-8-3899-2008, 2008.

Fiore, A. M., Naik, V., Spracklen, D. V., Steiner, A., Unger, N., Prather, M., Bergmann, D., Cameron-Smith, P. J., Cionni, I., Collins, W. J., Dalsoren, S., Eyring, V., Folberth, G. A., Ginoux, P., Horowitz, L. W., Josse, B., Lamarque, J.-F., MacKenzie, I. A., Nagashima, T., O’Connor, F. M., Righi, M., Rumbold, S. T., Shindell, D. T., Skeie, R. B., Sudo, K., Szopa, S., Takemura, T., and Zeng, G.: Global air quality and climate, Chem. Soc. Rev., 41, 6663-6683, 2012.

Froyd, K. D., Murphy, S. M., Murphy, D. M., de Gouw, J. A., Eddingsaas, N. C., and Wennberg, P. O.: Contribution of isoprenederived organosulfates to free tropospheric aerosol mass, Proc. Natl. Acad. Sci. USA, 107, 21360-21365, 2010.

Fuchs, H., Bohn, B., Hofzumahaus, A., Holland, F., Lu, K. D., Nehr, S., Rohrer, F., and Wahner, A.: Detection of $\mathrm{HO}_{2}$ by laserinduced fluorescence: calibration and interferences from $\mathrm{RO}_{2}$ radicals, Atmos. Meas. Tech., 4, 1209-1225, doi:10.5194/amt4-1209-2011, 2011. 
Fuchs, H., Hofzumahaus, A., Rohrer, F., Bohn, B., Brauers, T., Dorn, H.-P., Haeseler, R., Holland, F., Kaminski, M., Li, X., Lu, K., Nehr, S., Tillmann, R., Wegener, R., and Wahner, A.: Experimental evidence for efficient hydroxyl radical regeneration in isoprene oxidation, Nat. Geosci., 6, 1023-1026, 2013.

Ganzeveld, L., Bouwman, L., Stehfest, E., van Vuuren, D. P., Eickhout, B., and Lelieveld, J.: Impact of future land use and land cover changes on atmospheric chemistry-climate interactions, J. Geophys. Res., 115, D23301, doi:10.1029/2010JD014041, 2010.

Guenther, A., Karl, T., Harley, P., Wiedinmyer, C., Palmer, P. I., and Geron, C.: Estimates of global terrestrial isoprene emissions using MEGAN (Model of Emissions of Gases and Aerosols from Nature), Atmos. Chem. Phys., 6, 3181-3210, doi:10.5194/acp-63181-2006, 2006.

Haagen-Smit, A. J.: Chemistry and physiology of Los Angeles smog, Ind. Eng. Chem. Res., 44, 1342-1346, 1952.

Horowitz, L. W., Fiore, A. M., Milly, G. P., Cohen, R. C., Perring, A., Wooldridge, P. J., Hess, P. G., Emmons, L. K., and Lamarque, J.-F.: Observational constraints on the chemistry of isoprene nitrates over the eastern United States, J. Geophys. Res., 112, D12S08, doi:10.1029/2006JD007747, 2007.

Huntingford, C., Cox, P. M., Mercado, L. M., Sitch, S., Bellouin, N., Boucher, O., and Gedney, N.: Highly contrasting effects of different climate forcing agents on terrestrial ecosystem services, Philos. T. Roy. Soc. A, 369, 2026-2037, 2011.

Jeffries, H. E., Gery, M. W., and Carter, W. P. L.: Protocols for Evaluating Oxidant Mechanisms Used in Urban and Regional Models, Tech. rep., US Environmental Protection Agency, Atmospheric Research and Exposure Assessment Laboratory, Research Triangle Park, NC 27711, 1992.

Jenkin, M.: Review of the atmospheric chemistry of isoprene and evaluation of mechanisms for global modelling, Tech. rep., UK Met Office, Atmospheric Chemistry Services, Oakhampton, Devon, UK, 2012.

Jenkin, M. E., Saunders, S. M., and Pilling, M. J.: The tropospheric degradation of volatile organic compounds: a protocol for mechanism development, Atmos. Environ., 31, 81-104, 1997.

Kleinman, L., Daum, P., Lee, J., Lee, Y., Nunnermacker, L., Springston, S., Newman, L., Weinstein-Lloyd, J., and Sillman, S.: Dependence of ozone production on NO and hydrocarbons in the troposphere, Geophys. Res. Lett., 24, 2299-2302, 1997.

Kubistin, D., Harder, H., Martinez, M., Rudolf, M., Sander, R., Bozem, H., Eerdekens, G., Fischer, H., Gurk, C., Klüpfel, T., Königstedt, R., Parchatka, U., Schiller, C. L., Stickler, A., Taraborrelli, D., Williams, J., and Lelieveld, J.: Hydroxyl radicals in the tropical troposphere over the Suriname rainforest: comparison of measurements with the box model MECCA, Atmos. Chem. Phys., 10, 9705-9728, doi:10.5194/acp-10-97052010, 2010.

Kwok, E. S. C. and Atkinson, R.: Estimation of hydroxyl radical reaction-rate constants for gas-phase organic-compounds using a structure-reactivity relationship - an update, Atmos. Environ., 29, 1685-1695, 1995.

Lathiere, J., Hewitt, C. N., and Beerling, D. J.: Sensitivity of isoprene emissions from the terrestrial biosphere to 20th century changes in atmospheric $\mathrm{CO}_{2}$ concentration, climate, and land use, Glob. Change Biol., 24, GB1004, doi:10.1029/2009GB003548, 2010.
Lee, L., Teng, A. P., Wennberg, P. O., Crounse, J. D., and Cohen, R. C.: On rates and mechanisms of $\mathrm{OH}$ and $\mathrm{O}_{3}$ reactions with isoprene-derived hydroxy nitrates, J. Phys. Chem. A, 118, 1622-1637, 2014.

Lockwood, A. L., Shepson, P. B., Fiddler, M. N., and Alaghmand, M.: Isoprene nitrates: preparation, separation, identification, yields, and atmospheric chemistry, Atmos. Chem. Phys., 10, 6169-6178, doi:10.5194/acp-10-6169-2010, 2010.

Mao, J., Ren, X., Zhang, L., Van Duin, D. M., Cohen, R. C., Park, J.H., Goldstein, A. H., Paulot, F., Beaver, M. R., Crounse, J. D., Wennberg, P. O., DiGangi, J. P., Henry, S. B., Keutsch, F. N., Park, C., Schade, G. W., Wolfe, G. M., Thornton, J. A., and Brune, W. H.: Insights into hydroxyl measurements and atmospheric oxidation in a California forest, Atmos. Chem. Phys., 12, 8009-8020, doi:10.5194/acp-12-8009-2012, 2012.

McGillen, M. R., Archibald, A. T., Carey, T., Leather, K. E., Shallcross, D. E., Wenger, J. C., and Percival, C. J.: Structure-activity relationship (SAR) for the prediction of gas-phase ozonolysis rate coefficients: an extension towards heteroatomic unsaturated species, Phys. Chem. Chem. Phys., 13, 2842-2849, 2011.

Müller, J.-F., Peeters, J., and Stavrakou, T.: Fast photolysis of carbonyl nitrates from isoprene, Atmos. Chem. Phys., 14, 2497 2508, doi:10.5194/acp-14-2497-2014, 2014.

O'Connor, F. M., Johnson, C. E., Morgenstern, O., Abraham, N. L., Braesicke, P., Dalvi, M., Folberth, G. A., Sanderson, M. G., Telford, P. J., Voulgarakis, A., Young, P. J., Zeng, G., Collins, W. J., and Pyle, J. A.: Evaluation of the new UKCA climate-composition model - Part 2: The Troposphere, Geosci. Model Dev., 7, 41-91, doi:10.5194/gmd-7-41-2014, 2014.

Pacifico, F., Folberth, G. A., Jones, C. D., Harrison, S. P., and Collins, W. J.: Sensitivity of biogenic isoprene emissions to past, present, and future environmental conditions and implications for atmospheric chemistry, J. Geophys. Res., 117, D22302, doi:10.1029/2012JD018276, 2012.

Paulot, F., Crounse, J. D., Kjaergaard, H. G., Kuerten, A., St Clair, J. M., Seinfeld, J. H., and Wennberg, P. O.: Unexpected epoxide formation in the gas-phase photooxidation of isoprene, Science, 325, 730-733, 2009.

Paulot, F., Henze, D. K., and Wennberg, P. O.: Impact of the isoprene photochemical cascade on tropical ozone, Atmos. Chem. Phys., 12, 1307-1325, doi:10.5194/acp-12-1307-2012, 2012.

Peeters, J., Nguyen, T. L., and Vereecken, L.: $\mathrm{HO}_{x}$ radical regeneration in the oxidation of isoprene, Phys. Chem. Chem. Phys., 11, 5935-5939, 2009.

Perring, A. E., Bertram, T. H., Wooldridge, P. J., Fried, A., Heikes, B. G., Dibb, J., Crounse, J. D., Wennberg, P. O., Blake, N. J., Blake, D. R., Brune, W. H., Singh, H. B., and Cohen, R. C.: Airborne observations of total $\mathrm{RONO}_{2}$ : new constraints on the yield and lifetime of isoprene nitrates, Atmos. Chem. Phys., 9, 1451-1463, doi:10.5194/acp-9-1451-2009, 2009.

Pöschl, U., von Kuhlmann, R., Poisson, N., and Crutzen, P.: Development and intercomparison of condensed isoprene oxidation mechanisms for global atmospheric modeling, J. Atmos. Chem., 37, 29-52, 2000.

Ren, X., Olson, J. R., Crawford, J. H., Brune, W. H., Mao, J., Long, R. B., Chen, Z., Chen, G., Avery, M. A., Sachse, G. W., Barrick, J. D., Diskin, G. S., Huey, L. G., Fried, A., Cohen, R. C., Heikes, B., Wennberg, P. O., Singh, H. B., Blake, D. R., and Shet- 
ter, R. E.: $\mathrm{HO}_{x}$ chemistry during INTEX-A 2004: Observation, model calculation, and comparison with previous studies, J. Geophys. Res., 113, D05310, doi:10.1029/2007JD009166, 2008.

Sanderson, M., Jones, C., Collins, W., Johnson, C., and Derwent, R.: Effect of climate change on isoprene emissions and surface ozone levels, Geophys. Res. Lett., 30, 1936, doi:10.1029/2003GL017642, 2003.

Sandu, A. and Sander, R.: Technical note: Simulating chemical systems in Fortran90 and Matlab with the Kinetic PreProcessor KPP-2.1, Atmos. Chem. Phys., 6, 187-195, doi:10.5194/acp-6187-2006, 2006.

Savage, N. H., Agnew, P., Davis, L. S., Ordóñez, C., Thorpe, R., Johnson, C. E., O'Connor, F. M., and Dalvi, M.: Air quality modelling using the Met Office Unified Model (AQUM OS24-26): model description and initial evaluation, Geosci. Model Dev., 6, 353-372, doi:10.5194/gmd-6-353-2013, 2013.

Shepson, P. B., Mackay, E., and Muthuramu, K.: Henry's law constants and removal processes for several atmospheric $\beta$-hydroxy alkyl nitrates, Environ. Sci. Technol., 30, 3618-3623, 1996.

Sillman, S. and He, D. Y.: Some theoretical results concerning $\mathrm{O}_{3}-\mathrm{NO}_{x}$-VOC chemistry and $\mathrm{NO}_{x}$-VOC indicators, J. Geophys. Res., 107, 4659, doi:10.1029/2001JD001123, 2002.

Squire, O. J., Archibald, A. T., Abraham, N. L., Beerling, D. J., Hewitt, C. N., Lathière, J., Pike, R. C., Telford, P. J., and Pyle, J. A.: Influence of future climate and cropland expansion on isoprene emissions and tropospheric ozone, Atmos. Chem. Phys., 14, 1011-1024, doi:10.5194/acp-14-1011-2014, 2014.

Stevenson, D. S., Dentener, F. J., Schultz, M. G., Ellingsen, K., van Noije, T. P. C., Wild, O., Zeng, G., Amann, M., Atherton, C. S., Bell, N., Bergmann, D. J., Bey, I., Butler, T., Cofala, J., Collins, W. J., Derwent, R. G., Doherty, R. M., Drevet, J., Eskes, H. J., Fiore, A. M., Gauss, M., Hauglustaine, D. A., Horowitz, L. W., Isaksen, I. S. A., Krol, M. C., Lamarque, J.F., Lawrence, M. G., Montanaro, V., Müller, J.-F., Pitari, G., Prather, M. J., Pyle, J. A., Rast, S., Rodriguez, J. M., Sanderson, M. G., Savage, N. H., Shindell, D. T., Strahan, S. E., Sudo, K., and Szopa, S.: Multimodel ensemble simulations of present-day and near-future tropospheric ozone, J. Geophys. Res., 111, D08301, doi:10.1029/2005JD006338, 2006.

Stone, D., Evans, M. J., Edwards, P. M., Commane, R., Ingham, T., Rickard, A. R., Brookes, D. M., Hopkins, J., Leigh, R. J., Lewis, A. C., Monks, P. S., Oram, D., Reeves, C. E., Stewart, D., and Heard, D. E.: Isoprene oxidation mechanisms: measurements and modelling of $\mathrm{OH}$ and $\mathrm{HO}_{2}$ over a South-East Asian tropical rainforest during the OP3 field campaign, Atmos. Chem. Phys., 11, 6749-6771, doi:10.5194/acp-11-6749-2011, 2011.
Surratt, J. D., Chan, A. W. H., Eddingsaas, N. C., Chan, M. N., Loza, C. L., Kwan, A. J., Hersey, S. P., Flagan, R. C., Wennberg, P. O., and Seinfeld, J. H.: Reactive intermediates revealed in secondary organic aerosol formation from isoprene, Proc. Natl. Acad. Sci. USA, 107, 6640-6645, 2010.

von Kuhlmann, R., Lawrence, M. G., Pöschl, U., and Crutzen, P. J.: Sensitivities in global scale modeling of isoprene, Atmos. Chem. Phys., 4, 1-17, doi:10.5194/acp-4-1-2004, 2004.

Wang, K. and Shallcross, D.: Modelling terrestrial biogenic isoprene fluxes and their potential impact on global chemical species using a coupled LSM-CTM model, Atmos. Environ., 34, 2909-2925, 2000.

Warwick, N. J., Archibald, A. T., Ashworth, K., Dorsey, J., Edwards, P. M., Heard, D. E., Langford, B., Lee, J., Misztal, P. K., Whalley, L. K., and Pyle, J. A.: A global model study of the impact of land-use change in Borneo on atmospheric composition, Atmos. Chem. Phys., 13, 9183-9194, doi:10.5194/acp-13-91832013, 2013.

Whalley, L. K., Edwards, P. M., Furneaux, K. L., Goddard, A., Ingham, T., Evans, M. J., Stone, D., Hopkins, J. R., Jones, C. E., Karunaharan, A., Lee, J. D., Lewis, A. C., Monks, P. S., Moller, S. J., and Heard, D. E.: Quantifying the magnitude of a missing hydroxyl radical source in a tropical rainforest, Atmos. Chem. Phys., 11, 7223-7233, doi:10.5194/acp-11-72232011, 2011.

Wiedinmyer, C., Tie, X., Guenther, A., Neilson, R., and Granier, C.: Future changes in biogenic isoprene emissions: how might they affect regional and global atmospheric chemistry?, Earth Interact., 10, 1-19, doi:10.1175/EI174.1, 2006.

Wu, S., Mickley, L. J., Jacob, D. J., Logan, J. A., Yantosca, R. M., and Rind, D.: Why are there large differences between models in global budgets of tropospheric ozone?, J. Geophys. Res., 112, D05302, doi:10.1029/2006JD007801, 2007.

Wu, S., Mickley, L. J., Kaplan, J. O., and Jacob, D. J.: Impacts of changes in land use and land cover on atmospheric chemistry and air quality over the 21 st century, Atmos. Chem. Phys., 12, 15971609, doi:10.5194/acp-12-1597-2012, 2012.

Xie, Y., Paulot, F., Carter, W. P. L., Nolte, C. G., Luecken, D. J., Hutzell, W. T., Wennberg, P. O., Cohen, R. C., and Pinder, R. W. Understanding the impact of recent advances in isoprene photooxidation on simulations of regional air quality, Atmos. Chem. Phys., 13, 8439-8455, doi:10.5194/acp-13-8439-2013, 2013. 